\title{
Functional and evolutionary perspectives on gill structures of an obligate air-breathing, aquatic snail
}

\author{
Cristian Rodriguez ${ }^{\text {Equal first author, 1, 2, } 3}$, Guido I Prieto ${ }^{\text {Equal first author, } 3}$, Israel A Vega ${ }^{\text {Corresp., 1, 2, } 3}$, Alfredo Castro-Vazquez ${ }^{\text {Corresp. 1, 2, } 3}$ \\ 1 IHEM, CONICET, Universidad Nacional de Cuyo, Mendoza, Argentina \\ 2 Instituto de Fisiología, Facultad de Ciencias Médicas, Universidad Nacional de Cuyo, Mendoza, Argentina \\ 3 Departamento de Biología, Facultad de Ciencias Exactas y Naturales, Universidad Nacional de Cuyo, Mendoza, Argentina \\ Corresponding Authors: Israel A Vega, Alfredo Castro-Vazquez \\ Email address: israel.vega7@gmail.com, a.castrovazquez@gmail.com
}

Ampullariids are freshwater gastropods bearing a gill and a lung, thus showing different degrees of amphibiousness. In particular, Pomacea canaliculata (Caenogastropoda, Ampullariidae) is an obligate air-breather that relies mainly or solely on the lung for dwelling in poorly oxygenated water, for avoiding predators, while burying in the mud during aestivation, and for oviposition above water level. In this paper, we studied the morphological peculiarities of the gill in this species. We found (1) the gill and lung vasculature and innervation are intimately related, allowing alternation between water and air respiration; (2) the gill epithelium has features typical of a transporting rather than a respiratory epithelium; and (3) the gill has resident granulocytes within intraepithelial spaces that may serve a role for immune defence. Thus, the role in oxygen uptake may be less significant than the roles in ionic/osmotic regulation and immunity. Also, our results provide a morphological background to understand the dependence on aerial respiration of $P$. canaliculata. Finally, we consider these findings from a functional perspective in the light of the evolution of amphibiousness in the Ampullariidae, and discuss that master regulators may explain the phenotypic convergence of gill structures amongst this molluscan species and those in other phyla. 
2 Functional and evolutionary perspectives on gill 3 structures of an obligate air-breathing, aquatic snail

5

6

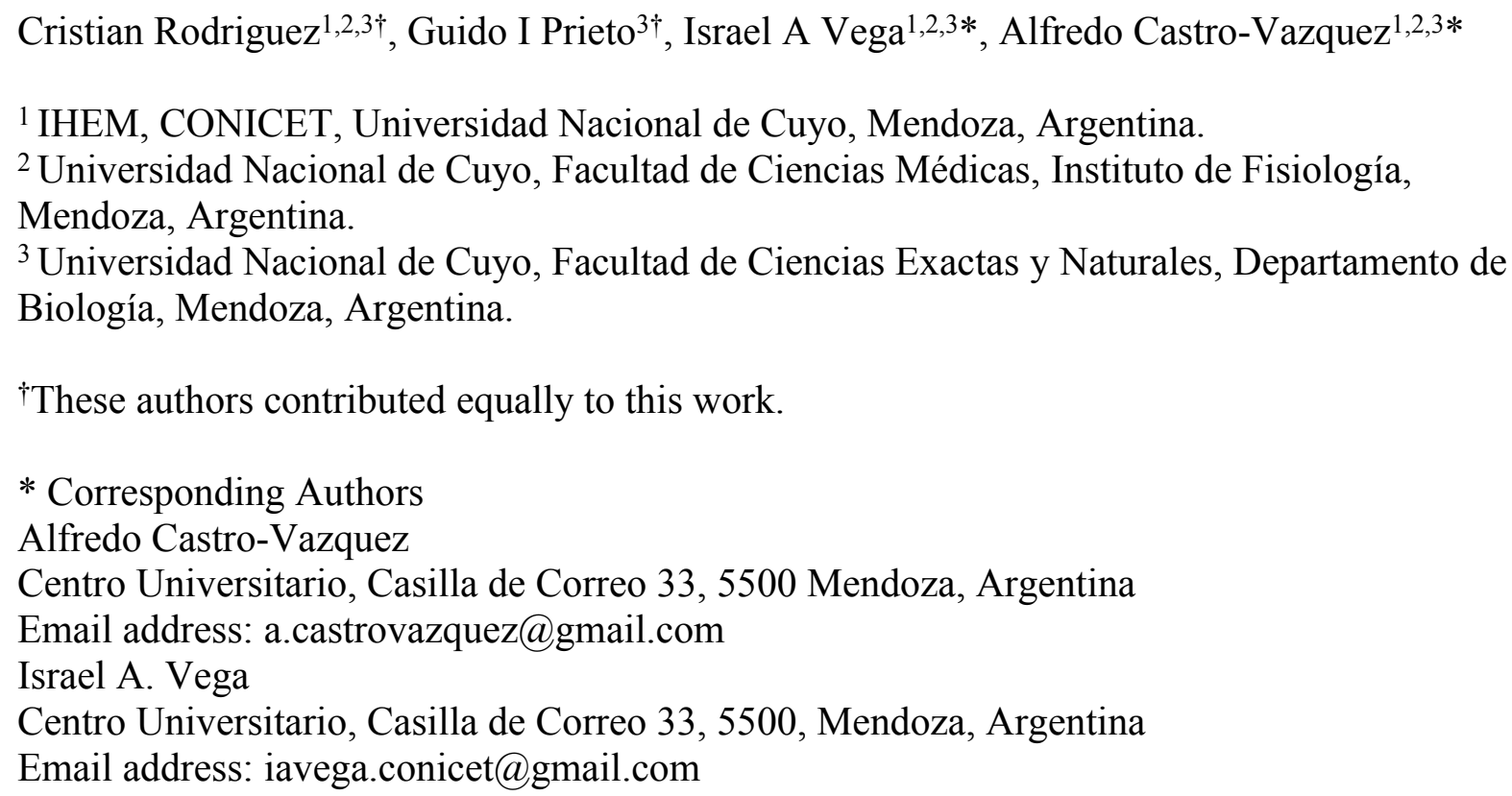

\begin{abstract}
Ampullariids are freshwater gastropods bearing a gill and a lung, thus showing different degrees of amphibiousness. In particular, Pomacea canaliculata (Caenogastropoda, Ampullariidae) is an obligate air-breather that relies mainly or solely on the lung for dwelling in poorly oxygenated water, for avoiding predators, while burying in the mud during aestivation, and for oviposition above water level. In this paper, we studied the morphological peculiarities of the gill in this species. We found (1) the gill and lung vasculature and innervation are intimately related, allowing alternation between water and air respiration; (2) the gill epithelium has features typical of a transporting rather than a respiratory epithelium; and (3) the gill has resident granulocytes within intraepithelial spaces that may serve a role for immune defence. Thus, the role in oxygen uptake may be less significant than the roles in ionic/osmotic regulation and immunity. Also, our results provide a morphological background to understand the dependence on aerial respiration of $P$. canaliculata. Finally, we consider these findings from a functional perspective in the light of the evolution of amphibiousness in the Ampullariidae, and discuss that master regulators may explain the phenotypic convergence of gill structures amongst this molluscan species and those in other phyla.
\end{abstract}

\title{
Introduction
}

Respiratory organs are identified as either gills or lungs, whether they are formed as protrusions or as invaginations of the respiratory mucosae. Gills are almost always used for aquatic respiration, while lungs are for aerial respiration, but in addition to respiration, these organs may also serve other functions (Maina 2000a; Maina 2002b). 
In bimodal breathers (i.e. aquatic animals that have retained a gill while developing a respiratory organ for breathing air), the gill may partially lose the respiratory role while acquiring others. In such cases, the respiratory function is supplied mainly by the air-breathing organ. In bimodal crustaceans and fishes, for example, the dependence on water comes in grades, the lesser water-dependent species having well-developed lungs that take up oxygen from the air and reduced or modified gills for ionic/osmotic regulation and $\mathrm{CO}_{2}$ excretion (Farrelly \& Greenaway 1987; Graham et al. 2007; Hughes \& Morgan 1973; Innes \& Taylor 1986; Low et al. 1988).

Most gastropods are marine and bear ctenidial gills (Haszprunar 1988), but some have adapted to terrestrial and amphibious life by developing lungs as specialisations of the pallial cavity (Semper 1881). Lungs occur in the subclasses Neritimorpha, Caenogastropoda and Heterobranchia (sensu Bouchet et al. 2017), although differing substantially in structure (Lindberg \& Ponder 2001). In the majority of lung-bearing gastropods, the pallial cavity itself has been modified as a lung (Lindberg \& Ponder 2001). Therefore, in these cases, the pallial cavity and the lung are homologous structures (Ruthensteiner 1997). In turn, in the family Ampullariidae (Caenogastropoda), the lung is a sac with a single cavity that extends into the roof of the pallial cavity and thus is not homologous with the pallial cavity.

Ampullariids comprise bimodal breathers that have also retained a true gill (i.e. a ctenidium). As other bimodal breathers, ampullariids show different degrees of amphibiousness, being the genera Afropomus, Saulea, Lanistes, Asolene, Felipponea, and Marisa more waterdependent than Pila and Pomacea (Hayes et al. 2009a). Amongst the latter, Pomacea canaliculata (Lamarck, 1822) is an obligate air-breather (Seuffert \& Martín 2010) that has a well-developed lung and a left nuchal lobe that is capable of being rolled into a siphon-like tube, and which uses as a snorkel to ventilate the lung while being submerged (Andrews 1965). Behavioural observations have shown that $P$. canaliculata relies mainly or solely on the lung for dwelling in poorly oxygenated waters, for avoiding predators (Ueshima \& Yusa 2015), while burying in the mud during aestivation (d'Orbigny 1847; Giraud-Billoud et al. 2011; GiraudBilloud et al. 2013; Hayes et al. 2015), and for oviposition above the water level (Hayes et al. 2009b). These facts make P. canaliculata (and the Ampullariidae in general) interesting models to investigate the suitability of respiratory organs, i.e. the gill and the lung, for the exchange of gases as well as the structural and functional integration of both organs. In a far-reaching perspective, such studies can help us understand the evolution of amphibiousness.

However, there is a paucity of data regarding the fine structure of caenogastropod gills. Previous studies have been limited to the hypertrophied ctenidia of hot vent caenogastropods (Provannidae; e.g., Endow \& Ohta 1989; Stein et al. 1988; Windoffer \& Giere 1997), which bear large quantities of endosymbiotic bacteria, but these studies have been aimed at elucidating the relationship between gill epithelial cells and their endosymbionts. In the Ampullariidae, the gill structure has been studied in Pila globosa (Swainson, 1822), Marisa cornuarietis (Linnaeus, 1758), and P. canaliculata (Andrews 1965; Lutfy \& Demian 1965; Prashad 1925), but only at the light microscopy level. In this paper, we present a thorough description of the gill of $P$. canaliculata at the anatomical (3D rendering of its blood system) and ultrastructural levels. Surprisingly, gill structures have never been investigated in this respect with fine structural techniques before. Therefore, our findings are a significant contribution to the knowledge of gill structures of ampullariids and the extremely large group of caenogastropods in general. Also, we discuss the significance of our findings from a functional and evolutionary perspective. 
91 Material and methods

92 Animals and culturing conditions

93 Animals (young adult males, $20 \mathrm{~mm}$ shell length) were obtained from the Rosedal strain of $P$.

94 canaliculata, whose origin and culture conditions have been described several times elsewhere

95 (e.g., Cueto et al. 2015; Rodriguez et al. 2018). Animals were immersed in water at $4^{\circ} \mathrm{C}$ for 20

9630 minutes both for relaxation and minimizing pain, before careful shell cracking. Procedures for

97 snail culture, sacrifice, and tissue sampling were approved by the Institutional Committee for the

98 Care and Use of Laboratory Animals (Comité Institucional para el Cuidado y Uso de Animales

99 de Laboratorio (CICUAL), Facultad de Ciencias Médicas, Universidad Nacional de Cuyo),

100 Approval Protocol N ${ }^{\circ} 55 / 2015$.

101

102

103

104

105

106

107

108

109

110

111

112

113

114

115

116

117

118

119

120

121

122

123

124

125

126

127

128

129

130

131

132

133

134

135

\section{Light and electron microscopy}

The gills from six animals were dissected out, fixed in dilute Bouin's fluid (1:2), dehydrated in a graded ethanol series, cleared in xylene and embedded in a 1:1 paraffin-resin mixture (Histoplast ${ }^{\circledR}$, Argentina). Sections (3-5 $\mu$ m thick) were obtained and stained with Gill's haematoxylin and eosin. The stained sections were examined and photographed under a Nikon Eclipse 80i microscope using Nikon DS-Fil-U3 camera and Nikon NIS-ELEMENT Image Software for image acquisition.

Additionally, the gill, lung and pericardium were dissected out as a single piece from two animals, and were used for 3D reconstruction of the gill's blood system and for descriptions of its innervation. For these purposes, the lung was collapsed before fixation in dilute Bouin's fluid, to reduce the size of the dissected sample. Then, samples were dehydrated, cleared, and embedded as described above. Serial sections (10 $\mu \mathrm{m}$ thick) were stained with Gill's haematoxylin and eosin and photographed with a Nikon Digital Sight DS-5M camera on a Nikon Alphaphot-2 YS2 microscope.

Also, gill samples from six animals, each one including $\sim 20$ consecutive leaflets, were prepared for scanning electron microscopy. For this purpose, the samples were fixed in dilute Bouin's fluid and some of them were microdissected to show different aspects of the leaflets. Afterwards, they were dehydrated in an ethanol series, passed through acetone and then critical point dried, mounted on aluminium stubs, coated with gold, and examined with a Jeol/EO JSM6490LV scanning electron microscope.

Furthermore, gill samples from six additional animals were fixed in Karnovsky's fluid ( $4 \%$ paraformaldehyde, $2.5 \%$ glutaraldehyde, dissolved in $0.1 \mathrm{M}$ phosphate buffer, $\mathrm{pH} 7.4$ ). One day later, tissues were washed thrice in phosphate buffer and transferred to $1 \%$ osmium tetroxide overnight. Afterwards, they were gradually dehydrated in a graded acetone series and finally embedded in Spurr's resin. Ultramicrotome sections $(\sim 200 \mathrm{~nm})$ were stained with toluidine blue and covered with DPX medium (Sigma-Aldrich) for fine histology. Silver-grey, ultrathin sections of gill samples were mounted on copper grids and stained with uranyl acetate and lead citrate, and examined with a Zeiss EM 900 transmission electron microscope.

\section{Computerised 3D rendering of the gill blood system}

Digital images of every fifth section were aligned manually using Reconstruct, version 1.1.0.0 (Fiala 2005), downloaded from Synapse Web, Kristen M. Harris, PI

(http://synapses.clm.utexas.edu). Then, the profile of identified structures (objects) were drawn with the mouse using the Trace tool. These traces were used for the 3D visualisation of object 
136

137

138

139

140

141

142

143

144

145

146

147

148

149

150

151

152

153

154

155

156

157

158

159

160

161

162

163

164

165

166

167

168

169

170

171

172

173

174

175

176

177

178

179

180

181

structures. The 3D model was exported as a VRML 2.0 file and embedded in a PDF as described by Ruthensteiner \& Heß (2008), using the 3D tool of Adobe Acrobat 9 Pro Extended software.

\section{Results}

\section{General organisation of the gill and related pallial organs}

The respiratory organs in the pallial complex are the gill and the lung. In addition, there are other organs that serve an accessory function, namely the siphon (=left nuchal lobe), the right nuchal lobe, and the pallial fold, which are depicted in Fig. 1A.

The gill extends from the left rear end of the mantle cavity (in the proximity of the pericardium and next to the ureter) to the right front side of the mantle cavity (close to the anus and the copulatory apparatus), and borders the posterior and right sides of the lung (Fig. 1A). The gill is formed by a single row of rather parallel leaflets (i.e. a ctenidial monopectinate condition) that hang from their bases in the roof of the mantle cavity (Fig. 1B). The gill leaflets have a rather triangular shape with free edges of unequal length (Supplemental Fig. S1). Relative to their orientation in the pallial cavity, the shorter free edge is referred here to as the afferent border, and the longer to as the efferent one. The basal border is anchored to the branchial base, where the main afferent and efferent vessels run, and therefore to the inner mantle.

The lung extends along the roof of the mantle cavity and communicates with the mantle cavity through the pneumostome, close to the base of the siphon. The pallial fold is a mucosal ridge that extends on the floor of the mantle cavity. It originates at the left posterior end of the mantle cavity, close to the pericardium, and runs to the right until it crosses the prostate (or the vagina in females) and then takes a diagonal anteroposterior direction towards the proximity of the right nuchal lobe. A functionally significant narrow channel is delimited between this fold, the gill, and the rear wall of the mantle cavity. The right nuchal lobe appears in fixed specimens as a short mucosal triangular fold hanging from the right side of the neck (Fig. 1A). In living animals, however, it is a thin scoop-like structure, which may occlude partly or totally the excretory mantle opening.

\section{Blood circulation in the gill}

The 3D rendering of the blood system of the gill (Fig. 2A-C and Supplemental Fig. S2) shows the afferent branchial vessel collects blood from ureteral efferents, particularly the efferent ureteral vessel (=efferent renal vein in Andrews 1965). Additionally, other gill afferents come from the rectal sinus and right pallial vessels that drain blood from the visceral hump. These afferents join the afferent branchial vessel, which continues as the afferent pulmonary vessel. Blood from the afferent branchial vessel flows through the gill leaflets to the efferent pulmobranchial vessel and then to the heart auricle, or alternatively, to the ventral afferent pulmonary vessel that irrigates the right half of the lung floor, thus integrating branchial and pulmonary circulation.

The haemocoel within each gill leaflet (Fig. 2D-F and Supplemental Fig. S2) extends as a lamina interrupted by trabeculae connecting both lateral surfaces of the leaflet, and is identified here as the laminar leaflet sinus. However, there are also two rather continuous haemocoelic sinuses in each leaflet: a marginal leaflet sinus runs along the free border of each leaflet, while the other, namely the basal leaflet sinus, extends at the base of the gill as a short cut between the afferent branchial vessel and the efferent pulmobranchial vessel. These sinuses communicate extensively with the laminar leaflet sinus, which also connects with the ventral afferent pulmonary vessel. 
182

183

184

185

186

187

188

189

190

191

192

193

194

195

196

197

198

199

200

201

202

203

204

205

206

207

208

209

210

211

212

213

214

215

216

217

218

219

220

221

222

223

224

225

226

227

\section{Branchial nerves and their origins}

Innervation of the gill of $P$. canaliculata comes from the supraoesophageal ganglion and an accessory visceral ganglion, which are diagrammatically shown in Fig. 3A.

Nerve branches of the branchial nerve arising from the supraoesophageal ganglion go through the lung roof (perhaps giving off neurites that innervate the lung roof) and end at the base of the gill leaflets (C. Rodriguez, G.I. Prieto, I.A. Vega \& A. Castro-Vazquez, unpubl. data). Each gill leaflet, however, shows a nerve along its efferent border (Fig. 3B). These leaflet nerves presumably originate from branches of the branchial nerve.

The accessory visceral ganglion is located along the supraoesophageal portion of the visceral loop, close to the pericardium, and gives off a nerve longitudinally traversing the ureter and running along the base of the gill, next to the afferent branchial vessel (Fig. 3C). The latter nerve has not been described for $P$. canaliculata (or for any other ampullariid) and it is here referred to as the branchial base nerve, which accompanies the afferent branchial vessel.

Also, neurite bundles arising from the copulatory ganglion are likely to join the branchial base nerve through its anterior end (Fig. 3D), at least in male animals. The copulatory ganglion lies close to the anterior end of the gill, in the proximity of the anus and the copulatory apparatus.

\section{The gill leaflets and their regions}

Four regions may be distinguished in each leaflet that are characterised by different epithelia (Figs. 4A and 5A). Under scanning electron microscopy, region I appears covered by microvillar cells and interspersed ciliary cells (Fig. 5A), whereas regions III and IV are respectively covered with cells bearing either long (Fig. 5B) or short cilia (Fig. 5C). Region II differs from region I in that it shows no ciliary cells (Fig. 4D-E). A summary of data is provided in Table 1.

The laminar leaflet sinus occupies the central space of each leaflet and is bordered by a thin fibromuscular layer, which underlies the epithelium (Fig. 4). The sinus is traversed by trabeculae (Fig. 4B-C), which in regions I and II are thinner than in region III (Fig. 4D-E).

The leaflet nerve (Fig. 6A) runs along the efferent marginal leaflet sinus and it is partly sheathed in a bundle of longitudinal muscle fibres, which is U-shaped in sections (Fig. 6A) and appears as a distinct structure under scanning electron microscopy (Fig. 6B). The leaflet nerve is composed of tightly packed neurites and some glial processes (Fig. 6C-D), whereas the muscular bundle is composed of thick fibres in a dense collagen matrix (Fig. 6E).

\section{Epithelial cell types}

The epithelium varies widely in the different regions of each leaflet (data is summarised in Table 2). In region I, it is columnar or low columnar $(20-40 \mu \mathrm{m})$, and it is mainly composed of either clear or dark microvillar, mitochondria-rich cells, hereafter referred to as $\alpha$-cells and $\beta$-cells, respectively (Fig. 7). Besides that, there are also interspersed ciliary cells, and a few secretory cells. These cells (identified as $\mathrm{C} 1, \mathrm{~S} 1$ and $\mathrm{S} 2$ cells, respectively) will be described for region IV, where they are more abundant.

Alpha-cells are characterised by euchromatic nuclei and conspicuous nucleoli. The cytoplasm contains numerous long mitochondria with well-defined cristae and glycogen deposits (Fig. 8A-C). Apically, these cells show few and rather short microvilli, and underlying membrane-bound bundles of electron-dense filaments/tubules. There is also a well-developed endomembrane vesicular system, as well as multivesicular (Fig. 8B) and multilamellar bodies (Fig. 8C). 
Contrasting with $\alpha$-cells, $\beta$-cells bear heterochromatic nuclei and a cytoplasm with numerous and tightly packed mitochondria (Fig. 8D-F). The surface area of the apical domain is increased by numerous and ramified microvilli (see Fig. 5A). An apical narrow band of homogeneous cytoplasm is seen below the microvilli, together with the apical ends of an extensive tubular system, which extends to the underlying mitochondrial conglomerate (Fig. 8E). Multivesicular bodies as well as presumptively degenerative bodies, such as myeloid bodies and fibrogranular material, are also abundant in the perinuclear region of these cells (Fig. 8F). Alphacells and $\beta$-cells alternate in approximately equal numbers. Numerous granulocytes lay inside epithelial intercellular spaces all along region I (Fig. 9), although they may also occur in other regions (see next Section).

A single cell type constitutes the epithelium in region III, which rests on a well-defined and electron-dense basal lamina (Fig. 10). It consists of cells with slender nuclei, very long cilia and short microvilli (C2 cells), and whose basolateral plasma membranes often enclose extensive and apparently dynamic intercellular spaces. The cytoplasm contains abundant rough endoplasmic reticulum and glycogen deposits (Fig. 10A-B). Transverse sections of cilia (Fig. 10C) show the typical 9+2 microtubule arrangement as well as membrane blebs (Fig. 10C, arrows). As $\alpha$-cells, these cells have membrane-bound bundles of electron-dense filaments/tubules in the subapical region (Fig. 10D).

The epithelium in region IV rests on a well-defined and electron-dense basal lamina and exhibits the same cell types as epithelium in region I, except for $\beta$-cells (Fig. 11A). However, ciliary $\mathrm{C} 1$ cells are the most abundant cell type here. They are characterised by a heterochromatic nucleus and an electron-dense cytoplasm that contains large dense-cored granules and glycogen deposits (Fig. 11B). The subapical region is similar to those of $\alpha$-cells, but apically there are finger-like microvilli and short cilia (Fig. 11B). Secretory S1 cells are mucous cells with merging granules containing an electron-dense mesh above the nucleus (Fig. 11C), and granules with a looser electron-dense mesh in the apical domain (Fig. 11D). These granules would correspond to the densely and loosely metachromatic accumulations seen in toluidine blue preparations (see Figs. 4E and 6A). On the other hand, secretory S2 cells have their cytoplasm almost filled with granules with a low electron-dense core (Fig. 11E), which are orthochromatic in toluidine blue preparations (Figs. 4E and 6A).

Epithelium in region II exhibits $\alpha$-cells, and abundant S1 and S2 cells (Fig. 4). The epithelia in regions III and IV are those directly exposed to the incoming water current that flows over the gill, and both the long and short cilia may contribute to the water movement.

\section{Apical intercellular junctions and the basolateral domain of epithelial cells}

All epithelia examined showed two types of cellular junctions in an orderly fashion. Apical adherent junctions (also called zonula adhaerens or 'desmosome belt'; Fig. 12A) are followed by septate junctions (Fig. 12B), which are often interrupted by intercellular canaliculi (Fig. 12A-B). Rather frequently, the canaliculi contain a globular, unidentified material (Fig. 12A). Below the septate junctions, the adjacent plasma membranes are separated by larger spaces, which increase in size towards the basal domain (Fig. 12C).

The basolateral domain of epithelial cells in all regions of a leaflet is a labyrinth of intermingled thin extensions that project towards the underlying connective tissue. There are conspicuous spaces between epithelial cells, which are frequently occupied by granulocytes (Fig. 9). Small neurite bundles, with or without accompanying glial cells, are also found in the intercellular spaces, thus providing direct intraepithelial innervation (Fig. 9A, arrows). A 
274

275

276

277

278

279

280

281

282

283

284

285

286

287

288

289

290

291

292

293

294

295

296

297

298

299

300

301

302

303

304

305

306

307

308

309

310

311

312

313

314

315

316

317

318

319

collagen matrix and sparse muscle fibres form the underlying connective tissue, which delimits the leaflet haemocoel. Neurite bundles accompanied by glial cells are frequently found in this tissue (see Fig. 9A), and these will be further described in the next Section.

A notable feature of this epithelium is the occurrence of granulocytes, with eccentric nuclei and conspicuous nucleoli, electron-dense granules, and areas of glycogen deposits. Granulocytes are often fully enclosed into expanded intercellular spaces (Fig. 9A-B), but sometimes, discontinuities in the mesh of basal projections of epithelial cells are found (Fig. 9C). These discontinuities connect the intercellular spaces directly with the basal lamina, which is evident because of its well-delimited lamina densa with interspersed electron-dense thickenings (Fig. 9C, arrowheads).

\section{Fibromuscular tissue and fine innervation}

Underlying the basal lamina there are muscle cells embedded in a collagen matrix (Fig. 13A). These muscle cells show myofibrils and scarce mitochondria. The cell surface shows numerous electron-dense anchoring junctions composed of an external brush-like plaque and an internal amorphous but electron-dense layer (Fig. 13B). The fibrils of the brush-like plaques are often continuous with those of other cell plaques or with thickenings of the lamina densa (Fig. 13A-B, arrowheads). These peculiar structures lie over clear cytoplasmic areas, which are traversed by thin cytoskeletal fibres.

Numerous neurite bundles that traverse the connective tissue and sometimes go into the epithelial intercellular spaces provide leaflet innervation. Neurites form bundles that are flanked by glial cell processes (Fig. 13C). Glial cells, or less frequently, uncovered neurites are in contact with muscle cells. Glial cells have rounded electron-dense, membrane-bound, granules of two different sizes (either $\sim 400 \mathrm{~nm}$ or $\sim 100 \mathrm{~nm}$ wide). Neurites have an electron-lucent axoplasm with neurofilaments. Fibre enlargements (presumptive nerve endings) contain $\sim 80 \mathrm{~nm}$ wide granules of variable electron density and $\sim 50 \mathrm{~nm}$ wide clear vesicles (Fig. 13C).

\section{Discussion}

\section{Comparative aspects of the gill leaflets and supporting structures}

Most gastropod ctenidia are composed of triangular leaflets (Lindberg \& Ponder 2001) that commonly have four ciliary fields, namely the lateral, frontal, abfrontal, and terminal. Lateral cilia are placed in two rows alongside the efferent border of the leaflet and provide ventilation, while the others cover the free edges of the leaflet and are engaged in cleansing (Lindberg \& Ponder 2001; Yonge 1947). The gill leaflets of Pomacea canaliculata are rather triangular and have well-developed lateral and frontal ciliary fields, which are here referred to as regions III and IV respectively (Fig. 4), but have no abfrontal or terminal cilia. The identity and disposition of the ciliary fields, as well as the rather small variation in shape and size of the leaflets along the gill in this species (Supplemental Fig. S1), are similar to those of Marisa cornuarietis (Demian 1965; Lutfy \& Demian 1965).

An efficient respiratory organ requires both a large and thin surface area. This respiratory surface should be fully exposed to the external medium to allow gas exchange (Maina \& West 2005). Therefore, some mechanical rigidity to support a deployed gill is indispensable to permit adequate gas exchange. Structures that support the weight of gills have been found in different taxa, such as the cartilaginous or bony supporting rods (gill rays), the interbranchial septa and the 'pillar cells' in fishes (Evans et al. 2005), the cuticle, the intralamellar septa, and the pillar cells in crustaceans (e.g., Farrelly \& Greenaway 1987; Farrelly \& Greenaway 1992), and the 
320

321

322

323

324

325

326

327

328

329

330

331

332

333

334

335

336

337

338

339

340

341

342

343

344

345

346

347

348

349

350

351

352

353

354

355

356

357

358

359

360

361

362

363

364

365

'supporting skeletal rods' and 'trabecular cells' in some molluscs (Nakao 1975; Ridewood 1903; Yonge 1947).

A 'skeletal rod' has been mentioned several times for the Ampullariidae (Berthold 1991; Haszprunar 1988; Ponder \& Lindberg 1997; Salvini-Plawen \& Haszprunar 1987), but no information on its microstructure or composition has been given. In P. canaliculata, we found a bundle of thick longitudinal muscle fibres embedded in a dense collagen matrix, which runs along the efferent margin of each gill leaflet (see Fig. 13). Therefore, it is a fibromuscular contractile structure and not a skeletal rod as has been suggested by earlier authors. It accompanies the leaflet nerve and the marginal leaflet sinus. It is worth noting that likely homologous muscular structures occur in the ampullariids M. cornuarietis (Lutfy \& Demian 1965) and Pila globosa (Prashad 1925). However, neither Lutfy \& Demian (1965) nor Prashad (1925) referred to the existence of a leaflet nerve. Considering that the three genera are closely related and that these authors used only light microscopy techniques, which are not best suited to recognise nervous tissue, they perhaps overlooked the leaflet nerve.

Trabecular cells are common structures in molluscan gills, whether they are ctenidia (Gregory et al. 1996; Le Pennec et al. 1988; Manganaro et al. 2012; Nuwayhid et al. 1978) or secondary gills (De Villiers \& Hodgson 1987; Jonas 1986). Trabeculae had been previously observed in ampullariids but were mistakenly considered as septa delimiting parallel blood sinuses (Andrews 1965; Lutfy \& Demian 1965; Prashad 1925; Ranjah 1942).

Nakao (1975) described in detail the trabecular cells of the bivalve Anodonta woodiana. They are modified muscular cells with a cytoplasm almost filled with myofibrils, scarce peripheral organelles, and anchoring junctions. The modified muscular cells underlying the basal lamina in P. canaliculata (see Fig. 13A-B) show similar characteristics, and thus may correspond to the anchoring part of the trabeculae shown in Figs. 4 and 5C.

\section{The gill as a respiratory organ}

The 3D rendering of the blood system of the gill in $P$. canaliculata suggests that the general pattern of branchial blood circulation is similar to that described by Andrews (1965) for the same species; although, there is a major difference that is worth mentioning (other differences can be found in Supplemental Table S1). The gill leaflets of $P$. canaliculata have a single laminar sinus interrupted by trabeculae and bounded by continuous sinuses at the leaflet borders and base, but with no transverse sinuses as interpreted by Andrews (1965) for the same species, or by Lutfy \& Demian (1965) for M. cornuarietis. This laminar arrangement implies a slow sheet-flow of blood, which likely facilitates the exchange of respiratory gases (Maina 2000b; Maina 2002a) and, perhaps more importantly, of ions. Moreover, this 'sheet-flow design' is in agreement with that found in other molluscan, crustacean, and fish gills (e.g., Booth 1978; Knight \& Knight 1986; Maina 1990). According to Andrews (1965), ciliary beating should conduct water between the gill leaflets towards a narrow channel bordered by the gill and the pallial fold. An exhalant water stream flows along the course of this channel, thus expelling urine and faeces (Andrews 1965). In this way, a countercurrent mechanism would occur between blood flowing through the leaflets and water flowing between them, facilitating $\mathrm{O}_{2}$ extraction from the water (see Fig. 2F).

However, in spite of having a countercurrent mechanism for $\mathrm{O}_{2}$ extraction, the gas exchange should be hindered by the thickness of the gill epithelium $(>20 \mu \mathrm{m})$, according to Fick's first law of diffusion (Maina \& West 2005). Also, the large number of mitochondria found in epithelial cells (see Figs. 6 and 7) indicates a high oxygen consumption, but this finding contradicts the idea that a respiratory tissue barrier must consume a minimal amount of the 
366

367

368

369

370

371

372

373

374

375

376

377

378

379

380

381

382

383

384

385

386

387

388

389

390

391

392

393

394

395

396

397

398

399

400

401

402

403

404

405

406

407

408

409

410

411

oxygen it extracts from the external medium (Maina 2000b). Indeed, a high oxygen consumption rate would be required for ion pumping against concentration gradients, which likely occurs in the gill epithelium. It should be considered, however, that a decrease in septate junctions' length -as occurs in leaflet region III- may shorten the distance between the external and internal media for the passage of molecules via the paracellular pathway ( $\mathrm{Yu}$ 2017). It is therefore expected that some downhill diffusion of gases followed this route, which requires no energy expenditure. However, the gill $\mathrm{CO}_{2}$ excretion would be higher than the $\mathrm{O}_{2}$ uptake, because of the higher solubility of $\mathrm{CO}_{2}$ in water. This is true, indeed, for many freshwater bimodal-breathing fishes (e.g., Evans et al. 2005) and crustaceans (e.g., Innes \& Taylor 1986), in which $\mathrm{CO}_{2}$ excretion occurs mainly through their gills, and $\mathrm{O}_{2}$ uptake occurs mainly through their lungs.

Thus, in the gill leaflets of $P$. canaliculata, deoxygenated blood coming from the afferent branchial vessel would reach the basal and marginal leaflet sinuses and would distribute through the laminar leaflet sinus, where incomplete oxygenation should happen (Fig. 2F). In this way, partially oxygenated blood would converge either to the efferent pulmobranchial vessel or the ventral afferent pulmonary vessel, as shown in Fig. $2 \mathrm{~F}$. The fact that partially oxygenated blood went directly to the lung floor would prove to be useful to complete the $\mathrm{O}_{2}$ uptake when the animal is submerged, because the gill might be insufficient to do that. Moreover, when on land, the collapse of leaflets and their laminar sinuses would force blood to follow the basal or marginal sinuses converging in the ventral afferent pulmonary vessel (Fig. $2 \mathrm{~F}$ ). In this way, there would be a shunt to the lung circulation, where oxygenation should reach its maximum (Maina 1990).

Alternatively, the gill may function as a ventilator, generating the left-to-right current that exposes water to the wall of the pallial cavity, where some gas exchange might occur, as suggested by Haszprunar (1992). Nonetheless, both the branchial and pallial surfaces together are still insufficient in $P$. canaliculata for respiration under water, because this species still needs air to ventilate the lung for adequate oxygen supply (Seuffert \& Martín 2010). Indeed, Seuffert \& Martín (2010) showed that P. canaliculata's microdistribution in the field is mostly restricted to 2-4 $\mathrm{m}$ from the nearest emergent substratum, and that impeding aerial respiration negatively affected its survivorship in aquaria.

\section{The gill as an ionic/osmotic regulator}

$P$. canaliculata is a hyperosmotic and hyperionic regulator and, like in many other freshwater animals, its gill may be involved in this regulation. Indeed, the gill of $P$. canaliculata has a high ion-ATPase activity, which suggests it is a site of ion uptake from the surrounding water, while its ureter would be a site of ion reabsorption from the primary urine (Taylor \& Andrews 1987).

As discussed above, the gill epithelium of $P$. canaliculata (Fig. 4 ) is characterised by tall columnar cells $(>20 \mu \mathrm{m})$ with apical specialisations, numerous mitochondria, and basolateral infoldings of the plasma membrane that enclose broad and presumably dynamic intercellular spaces. Additionally, these highly polarised cells have well-developed endomembrane systems and glycogen deposits (see Figs. 6 and 7). In contrast, the gill epithelium of M. cornuarietis is lower $(\sim 10 \mu \mathrm{m})$ than that of $P$. canaliculata, and has no intercellular spaces (Lutfy \& Demian 1965). It should be kept in mind that this species is more dependent on water than $P$. canaliculata (e.g., it lays gelatinous eggs underwater; Hayes et al. 2009a), and thus relies mainly on its gill for respiration.

There are two main morphological types of presumptive ion-transporting cells in $P$. canaliculata, which may be equivalent to the $\alpha$ and $\beta$ mitochondria-rich cells found in freshwater 
412 teleost fishes (for a review, see Evans et al. 2005; Wilson \& Laurent 2002) and to the 'fibrillar' 413 and 'tubulovesicular' types found in amphibians (Lewinson et al. 1987). Both $\alpha$ - and $\beta$-cells of $414 P$. canaliculata are indeed mitochondria-rich cells. Like those of fishes, $\alpha$-cells have an electron415 lucent cytoplasm, an apical membrane slightly concave with few and short apical specialisations, 416 and a well-developed subapical vesicular system (Figs. 6 and 7A). This cell type also resembles 417 the amphibian 'fibrillar cells' because of its membrane-bound bundles of electron-dense 418 filaments/tubules (Fig. 7B). On the other hand, $\beta$-cells have an electron-dense cytoplasm and complex apical specialisations of the plasma membrane (Figs. 6 and 7D), as fish $\beta$-cells do. They also have a well-developed tubulovesicular system that almost fills the cytoplasm between mitochondria (Fig. 7E), in close resemblance to the 'tubulovesicular' cell type of amphibians (Lewinson et al. 1987). It should be noted that the highlighted similarities between fish, amphibian and $P$. canaliculata's mitochondria-rich cell types suggest some similar regulatory mechanisms.

Thus, the features found in the gill epithelium of $P$. canaliculata contrast with those of the gill respiratory epithelia found in some other molluscan (e.g., Fischer et al. 1990; Gregory et al. 1996; Le Pennec et al. 1988; Manganaro et al. 2012; Nuwayhid et al. 1978) and non-molluscan taxa (e.g., Evans et al. 2005; Luquet et al. 2002) that are more dependent on water breathing, and which show cubic or squamous cells, with low nuclear/cytoplasmic ratios and a low content of mitochondria and other organelles. In turn, the gill structures found in P. canaliculata are more similar to those of transporting epithelia (Berridge \& Oschman 2012), such as those of the vertebrate small intestine (e.g., Flik \& Verbost 1993), gallbladder (e.g., Housset et al. 2016), and renal tubules (e.g., Yu 2017), and of the ionic/osmotic regulatory epithelia in the gills of crustaceans (e.g., Luquet et al. 2002; McNamara \& Faria 2012) and fishes (e.g., McDonald et al. 1991). Taken together, these features may determine $P$. canaliculata to be an obligate airbreathing species, whose gill structures seem better suited for ionic/osmotic regulation than for $\mathrm{O}_{2}$ uptake.

\section{The gill as an immune barrier}

In general, integumentary structures are the first barrier to microbial intruders, and as such, the gill is one of these structures preventing their access from the mantle cavity. In fact, $P$.

canaliculata must also cope with the diverse symbiotic organisms that frequently dwell in the mantle cavity (Vega et al. 2006). Mucus secretion and water currents may be unfavourable for the settling of many organisms (Vega et al. 2006). Abundant mucus is found covering the gill epithelium, which is likely secreted by the large number of secretory cells that occur in regions II and IV (Figs. 4 and 10). These cells are of two types, S1 and S2, that may correspond to the 'mucous' and 'gland' cell types in M. cornuarietis, respectively (Lutfy \& Demian 1965).

However, the gill is also a potential barrier because of its position in the circulation, as are the kidney and lung in P. canaliculata (Rodriguez et al. 2018). Indeed, most blood coming from the cephalopodal mass and the visceral hump has to pass through the gill before reaching the heart to re-enter the general circulation. Thus, the gill itself, beyond its role as part of the integumentary barrier, may also function as a filter for blood-borne microorganisms.

The conspicuous occurrence of granulocytes amongst epithelial intercellular spaces (Figs. 4 and 8) suggests these cells would serve in immune defense in this organ. Granulocytes are also frequent in the gill of $M$. cornuarietis, but they appear subepithelial in the drawings of Lutfy \& Demian (1965) rather than intraepithelial. The occurrence of immunocompetent cells within epithelial intercellular spaces is a widespread feature amongst the gills of bivalves (e.g., de 
458

459

460

461

462

463

464

465

466

467

468

469

470

471

472

473

474

475

476

477

478

479

480

481

482

483

484

485

486

487

488

489

490

491

492

493

494

495

496

497

498

499

500

501

502

503

Oliveira David et al. 2008; Gregory et al. 1996) and fishes (e.g., Hughes \& Morgan 1973). The granulocytes found in the gill were larger than those found in the general circulation of $P$. canaliculata and, in spite of being the less frequent cell type in the circulation (see Cueto et al. 2015), the intercellular spaces had only granulocytes within them.

There is evidence of a kind of 'compound exocytosis' (Pickett \& Edwardson 2006) leading to granulocyte degranulation in $P$. canaliculata (Cueto et al. 2015). Granulocyte degranulation in bivalves (e.g., Ciacci et al. 2009; Cheng et al. 1975; Foley \& Cheng 1977; Mohandas et al. 1985; Rebelo et al. 2013) has been related to the release of lysozyme and other hydrolytic enzymes that may kill bacteria and fungi, and Ottaviani (1991) has reported lysozyme from haemocytes of a gastropod. Therefore, it is likely that granulocytes occurring in the intercellular spaces of the gill epithelium are there serving a defensive role in $P$. canaliculata.

\section{Nervous control of the gill}

The gill is mainly innervated from the supraoesophageal ganglion and the accessory visceral ganglion found in P. canaliculata (see Fig. 3A), which are part of the ganglionar visceral loop (Chase 2002) that also includes the suboesophageal and the visceral ganglia (Berthold 1991; Hylton Scott 1957). The origin of the gill innervation in the supraoesophageal and accessory visceral ganglia supports the view of the adult's gill as the post-torsional left gill (Lindberg \& Sigwart 2015), but which has been displaced to the right by the development of the lung (Koch et al. 2009). The branchial nerve also innervates the osphradium and the muscular region of the lung that surrounds the pneumostome (C. Rodriguez, G.I. Prieto, I.A. Vega \& A. CastroVazquez, unpubl. data). The osphradium has been shown to sense ionic or $\mathrm{O}_{2} / \mathrm{CO}_{2}$ levels in water, amongst other chemosensory functions in several gastropods (Lindberg \& Sigwart 2015). It also may be involved in the switch between the behavioural modes of branchial and lung respiration (C. Rodriguez, G.I. Prieto, I.A. Vega \& A. Castro-Vazquez, unpubl. data), and in the regulation of the gill ionic/osmotic functions in $P$. canaliculata.

We have not found any neuroepithelial cells similar to those found in fish gills (Bailly et al. 1992; Dunel-Erb et al. 1982; Jonz \& Nurse 2003). The neurite supply to the gill leaflets is rich and spread in the connective tissue, the laminar sinus cells, and the epithelial basolateral domain (see Fig. 3), as has been described in the gill filaments of Anodonta (Nakao 1975) and in the gill leaflets of many fishes (e.g., Jonz \& Zaccone 2009). It also includes glial cell processes (Fig. 12C) similar to those referred by Nicaise (1973) in heterobranchs.

The sensory information coming from the osphradium and/or the gill epithelium may be integrated in the visceral loop and may trigger different responses through efferent pathways. For example, controlling the state of the intercellular spaces could either increase or decrease the epithelium permeability, thus regulating respiratory or ionic/osmotic functions, as there has been described in fish gills (e.g., Jonz \& Nurse 2006). Efferent pathways may also be involved in the regulation of vascular resistance through the gill leaflets by altering the stretching of trabecular cells, as has been proposed for bivalves (Nakao 1975) and as it occurs in pillar cells of fish gills (Jonz \& Zaccone 2009). Indeed, numerous neurites were often found in close contact with these modified muscle cells (see Fig. 12). Finally, other motor innervation would involve that associated with the muscular bundle along the efferent border of the gill leaflet (see Fig. 6).

\section{The evolution of amphibiousness: the family Ampullariidae as a case study}

The family Ampullariidae has been proposed as a model for evolutionary biology because of its long evolutionary history that traces back to the Jurassic ( $\sim 60$ million years ago), wide 
504

505

506

507

508

509

510

511

512

513

514

515

516

517

518

519

520

521

522

523

524

525

526

527

528

529

530

531

532

533

534

535

536

537

538

539

540

541

542

543

544

545

546

547

548

549

geographic distribution (through Africa, Asia, and the Americas), and high diversity $(\sim 120$ currently valid species) (Hayes et al. 2009a). These characteristics, along with the different degrees of air dependence ampullariids show, make this family an interesting model to study the evolution of amphibiousness (Hayes et al., 2015). Important advances have been made in elucidating the evolution of traits related to amphibiousness in Ampullariidae. In particular, the evolution of aerial oviposition has received considerable attention (e.g., Hayes et al. 2009a; Ip et al. 2019; Mu et al. 2017; Sun et al. 2019). However, a comparative study on the morphology, function, and development of the respiratory organs amongst the Ampullariidae is still lacking.

As mentioned above, the development of a lung has allowed a shift in the biological role of the gill to the detriment of its capacity for oxygen uptake in bimodal-breathing crustaceans and fishes. Our results suggest this may also be the case amongst the Ampullariidae and encourage the search for similar patterns through the comparison of the respiratory organs, and their relative functions, between ampullariid species with different degrees of air dependence.

Finally, it is worth emphasising the convergence of gill structures of $P$. canaliculata with those in phylogenetically distant taxa, such as arthropods (e.g., Farrelly \& Greenaway 1987; Luquet et al. 2002; Maina 1990) and fishes (e.g., Evans et al. 2005; Laurent \& Dunel 1980; Low et al. 1988; McDonald et al. 1991). Indeed, these may be cases of phenotypic convergence in which similar genetic mechanisms, such as the existence of conserved master regulators, can lead to convergence in form and function in independent and often distant lineages (Stern 2013). The existence of master regulators, such as the Hox and ParaHox genes, has been shown in ampullariids (Sun et al. 2019) and in representatives of other classes of molluscs (De Oliveira et al. 2016). Future studies may be aimed at elucidating whether conserved master regulators are involved in the development of similar structures in the gill of P. canaliculata.

\section{Conclusions}

1. We have confirmed interpretations of preceding authors regarding the vasculature and innervation of the gill of $P$. canaliculata and their implications. Namely, (a) that the gill vasculature is connected in series with that of the lung, in such a way that blood may complete oxygenation in the latter organ, and (b) that the origin of the gill innervation in the main and accessory supraoesophageal ganglia supports the view of the adult's gill as the post-torsional left gill, but which has been displaced to the right by the development of the lung.

2. When the animal is under water, the gill surface potentially available for gas exchange is large, but is covered by a rather thick epithelium $(>20 \mu \mathrm{m})$, with no cubic or squamous cells as in the gills of crustaceans and fishes. Ultrastructural evidence suggests that the only structures that perhaps facilitate oxygen uptake would be those involved in the paracellular pathway.

3. Also, in case the branchial leaflets collapse when the animal is out of the water, blood may bypass the leaflets and go directly to the lung through a shunt formed between the basal branchial sinuses and the ventral afferent pulmonary vessel.

4. The leaflet architecture is uniform throughout the whole gill, i.e. there is not a respiratory and ionic regionalisation of the gill as there occurs in other taxa (e.g., crustaceans).

However, four regions may be recognised within each leaflet, each presumably associated with specific functions: region I with ionic/osmotic regulation, regions II and IV with mucous secretion, regions III and IV with water circulation, and region III to gas exchange through the paracellular pathway. 
5. Our findings showed that the gill epithelium has features of a transporting epithelium rather than a respiratory one. Specifically, the branchial epithelium has (1) developed apical specialisations and basolateral infoldings, (2) occluding junctions, (3) extensive, and likely dynamic, intercellular spaces, (4) a high density of mitochondria, and (5) an underlying rich nerve supply. Altogether, these features suggest the gill in P. canaliculata would be more suitable for ionic/osmotic regulation than for oxygen uptake, which partly explain why $P$. canaliculata is an obligate air-breathing species.

6. The gill may function as an immune barrier by secreting mucus to prevent the access of intruders from the mantle cavity, but also to prevent the spread of blood-borne microorganisms, in which granulocytes may participate.

\section{Acknowledgements}

The authors appreciate the generous help of Elisa Bocanegra, Sergio A. Carminati, Norberto F. Domizio, Mabel Fóscolo, María Silvina Lassa, and María Paula López.

\section{References}

Andrews EB. 1965. The functional anatomy of the mantle cavity, kidney and blood system of some pilid gastropods (Prosobranchia). Journal of Zoology 146:70-94.

Bailly Y, Dunel-Erb S, and Laurent P. 1992. The neuroepithelial cells of the fish gill filament: Indolamine-immunocytochemistry and innervation. The Anatomical Record 233:143-161. Berridge MJ, and Oschman JL. 2012. Transporting epithelia: Elsevier.

Berthold T. 1991. Vergleichende Anatomie, Phylogenie und historische Biogeographie der Ampullariidae (Mollusca, Gastropoda). Abhandlungen des Naturwissenschaftlichen Vereins in Hamburg 29:1-257.

Booth JH. 1978. The distribution of blood flow in the gills of fish: application of a new technique to rainbow trout (Salmo gairdneri). Journal of Experimental Biology 73:119129.

Bouchet P, Rocroi J-P, Hausdorf B, Kaim A, Kano Y, Nützel A, Parkhaev P, Schrödl M, and Strong EE. 2017. Revised classification, nomenclator and typification of gastropod and monoplacophoran families. Malacologia 61:1-527.

Ciacci C, Citterio B, Betti M, Canonico B, Roch P, and Canesi L. 2009. Functional differential immune responses of Mytilus galloprovincialis to bacterial challenge. Comparative Biochemistry and Physiology Part B: Biochemistry and Molecular Biology 153:365-371.

Cueto JA, Rodriguez C, Vega IA, and Castro-Vazquez A. 2015. Immune defenses of the invasive apple snail Pomacea canaliculata (Caenogastropoda, Ampullariidae): Phagocytic hemocytes in the circulation and the kidney. PLOS ONE 10:e0123964. 10.1371/journal.pone. 0123964

Chase R. 2002. Behavior and its neural control in gastropod molluscs. Oxford: Oxford University Press.

Cheng TC, Rodrick GE, Foley DA, and Koehler SA. 1975. Release of lysozyme from hemolymph cells of Mercenaria mercenaria during phagocytosis. Journal of Invertebrate Pathology 25:261-265.

d‘Orbigny A. 1847. Voyage dans 1‘Amérique Méridionale. Paris: C.P. Bertrand. p 711.

De Oliveira A, Wollesen T, Kristof A, Scherholz M, Redl E, Todt C, Bleidorn C, and Wanninger A. 2016. Comparative transcriptomics enlarges the toolkit of known developmental genes in mollusks. BMC Genomics 17:905. 
596

597

598

599

600

601

602

603

604

605

606

607

608

609

610

611

612

613

614

615

616

617

618

619

620

621

622

623

624

625

626

627

628

629

630

631

632

633

634

635

636

637

638

639

640

641

de Oliveira David JA, Salaroli RB, and Fontanetti CS. 2008. Fine structure of Mytella falcata (Bivalvia) gill filaments. Micron 39:329-336.

De Villiers C, and Hodgson A. 1987. The structure of the secondary gills of Siphonaria capensis (Gastropoda: Pulmonata). Journal of Molluscan Studies 53:129-138.

Demian ES. 1965. The respiratory system and the mechanism of respiration in Marisa cornuarietis (L.). Arkiv för Zoologi 17:539-560.

Dunel-Erb S, Bailly Y, and Laurent P. 1982. Neuroepithelial cells in fish gill primary lamellae. Journal of Applied Physiology 53:1342-1353.

Eertman RHM. 1996. Comparative study on gill morphology of gastropods from Moreton Bay, Queensland. Molluscan Research 17:3-20.

Endow K, and Ohta S. 1989. The symbiotic relationship between bacteria and a mesogastropod snail, Alviniconcha hessleri, collected from hydrothermal vents of the Mariana Back-Arc Basin. Bulletin of Japanese Society of Microbial Ecology 3:73-82.

Evans DH, Piermarini PM, and Choe KP. 2005. The multifunctional fish gill: dominant site of gas exchange, osmoregulation, acid-base regulation, and excretion of nitrogenous waste. Physiological Reviews 85:97-177.

Farrelly C, and Greenaway P. 1987. The morphology and vasculature of the lungs and gills of the soldier crab, Mictyris longicarpus. Journal of Morphology 193:285-304.

Farrelly CA, and Greenaway P. 1992. Morphology and ultrastructure of the gills of terrestrial crabs (Crustacea, Gecarcinidae and Grapsidae): Adaptations for air-breathing. Zoomorphology 112:39-49.

Fiala JC. 2005. Reconstruct: a free editor for serial section microscopy. Journal of Microscopy 218:52-61.

Fischer FP, Alger M, Cieslar D, and Krafczyk HU. 1990. The chiton gill: Ultrastructure in Chiton olivaceus (Mollusca, Polyplacophora). Journal of Morphology 204:75-87.

Flik G, and Verbost P. 1993. Calcium transport in fish gills and intestine. Journal of Experimental Biology 184:17-29.

Foley DA, and Cheng TC. 1977. Degranulation and other changes of molluscan granulocytes associated with phagocytosis. Journal of Invertebrate Pathology 29:321-325.

Giraud-Billoud M, Abud M, Cueto J, Vega I, and Castro-Vazquez A. 2011. Uric acid deposits and estivation in the invasive apple-snail, Pomacea canaliculata. Comparative \& Biochemical Physiology Part A 158:506-512.

Giraud-Billoud M, Vega IA, Rinaldi Tosi ME, Abud MA, Calderón ML, and Castro-Vazquez A. 2013. Antioxidant and molecular chaperone defenses during estivation and arousal in the South American apple-snail Pomacea canaliculata. Journal of Experimental Biology 216:614-622.

Graham J, Lee H, and Wegner N. 2007. Transition from water to land in an extant group of fishes: Air breathing and the acquisition sequence of adaptations for amphibious life in Oxudercine gobies. In: Fernandes MN, Rantin FT, Mogens LG, and Kapoor B, eds. Fish Respiration and Environment: Science Publishers, 255-288.

Gregory M, George R, and McClurg T. 1996. The architecture and fine structure of gill filaments in the brown mussel, Perna perna. African Zoology 31:193-207.

Haszprunar G. 1988. On the origin and evolution of major gastropod groups, with special reference to the Streptoneura. Journal of Molluscan Studies 54:367-441.

Haszprunar G. 1992. The first molluscs - small animals. Bolletino di Zoologia (Italian Journal of Zoology) 59:1-16.

Peer] reviewing PDF | (2019:01:34352:2:0:NEW 12 Jun 2019) 
642

643

644

645

646

647

648

649

650

651

652

653

654

655

656

657

658

659

660

661

662

663

664

665

666

667

668

669

670

671

672

673

674

675

676

677

678

679

680

681

682

683

684

685

Hayes KA, Burks R, Castro-Vazquez A, Darby PC, Heras H, Martín PR, Qiu J-W, Thiengo SC, Vega IA, Yusa Y, Wada T, Burela S, Cadierno MP, Cueto JA, Dellagnola FA, Dreon MS, Frassa VM, Giraud-Billoud M, Godoy MS, Ituarte S, Koch E, Matsukura K, Pasquevich Y, Rodriguez C, Saveanu L, Seuffert ME, Strong EE, Sun J, Tamburi NE, Tiecher MJ, Turner RL, Valentine-Darby P, and Cowie RH. 2015. Insights from an integrated view of the biology of apple snails (Caenogastropoda: Ampullariidae). Malacologia 58:245-302.

Hayes KA, Cowie RH, Jørgensen A, Schultheiß R, Albrecht C, and Thiengo SC. 2009a. Molluscan models in evolutionary biology: Apple snails (Gastropoda: Ampullariidae) as a system for addressing fundamental questions. American Malacological Bulletin 27:4758.

Hayes KA, Cowie RH, and Thiengo SC. 2009b. A global phylogeny of apple snails: Gondwanan origin, generic relationships, and the influence of outgroup choice (Caenogastropoda: Ampullariidae). Biological Journal of the Linnean Society 98:61-76.

Housset C, Chrétien Y, Debray D, and Chignard N. 2016. Functions of the gallbladder. Comprehensive Physiology 6:1549-1577.

Hughes G, and Morgan M. 1973. The structure of fish gills in relation to their respiratory function. Biological Reviews 48:419-475.

Hylton Scott MI. 1957. Estudio morfológico y taxonómico de los ampulláridos de la República Argentina. Revista del Museo Argentino de Ciencias Naturales "Bernardino Rivadavia" 3:233-333.

Hyman LH. 1967. The Invertebrates. New York: McGraw-Hill.

Innes A, and Taylor E. 1986. The evolution of air-breathing in crustaceans: A functional analysis of branchial, cutaneous and pulmonary gas exchange. Comparative Biochemistry and Physiology Part A: Physiology 85:621-637.

Ip JC, Mu H, Zhang Y, Sun J, Heras H, Chu KH, and Qiu J-W. 2019. Understanding the transition from water to land: Insights from multi-omic analyses of the perivitelline fluid of apple snail eggs. Journal of Proteomics 194:79-88.

Jonas M. 1986. Ultrastructural of the gill epithelia of the dorid nudibranchs Archidoris pseudoargus (von Rapp, 1827) and Peltodoris atromaculata Bergh, 1880 (Gastropoda: Opisthobranchia). The Veliger 29:207-216.

Jonz MG, and Nurse CA. 2003. Neuroepithelial cells and associated innervation of the zebrafish gill: a confocal immunofluorescence study. Journal of Comparative Neurology 461:1-17.

Jonz MG, and Nurse CA. 2006. Epithelial mitochondria-rich cells and associated innervation in adult and developing zebrafish. Journal of Comparative Neurology 497:817-832.

Jonz MG, and Zaccone G. 2009. Nervous control of the gills. Acta Histochemica 111:207-216.

Knight J, and Knight R. 1986. The blood vascular system of the gills of Pholas dactylus L. (Mollusca, Bivalvia, Eulamellibranchia). Philosophical Transactions of the Royal Society of London B 313:509-523.

Koch E, Winik BC, and Castro-Vazquez A. 2009. Development beyond the gastrula stage and digestive organogenesis in the apple-snail Pomacea canaliculata (Architaenioglossa, Ampullariidae). Biocell 33:49-65.

Laurent P, and Dunel S. 1980. Morphology of gill epithelia in fish. American Journal of Physiology-Regulatory, Integrative and Comparative Physiology 238:R147-R159.

Peer] reviewing PDF | (2019:01:34352:2:0:NEW 12 Jun 2019) 
686

687

688

689

690

691

692

693

694

695

696

697

698

699

700

701

702

703

704

705

706

707

708

709

710

711

712

713

714

715

716

717

718

719

720

721

722

723

724

725

726

727

728

729

730
Le Pennec M, Beninger P, and Herry A. 1988. New observations of the gills of Placopecten magellanicus (Mollusca: Bivalvia), and implications for nutrition. Marine Biology 98:229-237.

Lewinson D, Rosenberg M, and Warburg M. 1987. Ultrastructural and ultracytochemical studies of the gill epithelium in the larvae of Salamandra salamandra (Amphibia, Urodela). Zoomorphology 107:17-25.

Lindberg DR, and Ponder WF. 2001. The influence of classification on the evolutionary interpretation of structure a re-evaluation of the evolution of the pallial cavity of gastropod molluscs. Organisms Diversity \& Evolution 1:273-299.

Lindberg DR, and Sigwart JD. 2015. What is the molluscan osphradium? A reconsideration of homology. Zoologischer Anzeiger-A Journal of Comparative Zoology 256:14-21.

Low W, Lane D, and Ip Y. 1988. A comparative study of terrestrial adaptations of the gills in three mudskippers: Periophthalmus chrysospilos, Boleophthalmus boddaerti, and Periophthalmodon schlosseri. Biological Bulletin:434-438.

Luquet C, Genovese G, Rosa G, and Pellerano G. 2002. Ultrastructural changes in the gill epithelium of the crab Chasmagnathus granulatus (Decapoda: Grapsidae) in diluted and concentrated seawater. Marine Biology 141:753-760.

Lutfy RG, and Demian ES. 1965. The histology of the respiratory organs of Marisa cornuarietis (L.). Arkiv för Zoologi 18:51-71.

Maina JN. 1990. The morphology of the gills of the freshwater African crab Potamon niloticus (Crustacea: Brachyura: Potamonidae): A scanning and transmission electron microscopic study. Journal of Zoology 221:499-515.

Maina JN. 2000a. Comparative respiratory morphology: themes and principles in the design and construction of the gas exchangers. Anatomical Record (New Anatomist) 261:25-44.

Maina JN. 2000b. Is the sheet-flow design a 'frozen core'(a Bauplan) of the gas exchangers?: Comparative functional morphology of the respiratory microvascular systems: illustration of the geometry and rationalization of the fractal properties. Comparative Biochemistry and Physiology-Part A: Molecular \& Integrative Physiology 126:491-515.

Maina JN. 2002a. Sheet flow design in the vasculature of gas exchangers. In: Maina JN, ed. Fundamental Structural Aspects and Features in the Bioengineering of the Gas Exchangers: Comparative Perspectives. Berlin; Heidelberg; New York; Barcelona; Hong Kong; London; Milan; Paris; Tokyo: Springer, 47-49.

Maina JN. 2002b. Structure, function and evolution of the gas exchangers: comparative perspectives. Journal of Anatomy 201:281-304.

Maina JN, and West JB. 2005. Thin and strong! The bioengineering dilemma in the structural and functional design of the blood-gas barrier. Physiological Reviews 85:811-844.

Manganaro M, Laurà R, Guerrera MC, Lanteri G, Zaccone D, and Marino F. 2012. The morphology of gills of Haliotis tuberculata (Linnaeus, 1758). Acta Zoologica 93:436443.

McDonald DG, Cavdek V, and Ellis R. 1991. Gill design in freshwater fishes: interrelationships among gas exchange, ion regulation, and acid-base regulation. Physiological Zoology 64:103-123.

McNamara JC, and Faria SC. 2012. Evolution of osmoregulatory patterns and gill ion transport mechanisms in the decapod Crustacea: A review. Journal of Comparative Physiology B 182:997-1014.

PeerJ reviewing PDF | (2019:01:34352:2:0:NEW 12 Jun 2019) 
731

732

733

734

735

736

737

738

739

740

741

742

743

744

745

746

747

748

749

750

751

752

753

754

755

756

757

758

759

760

761

762

763

764

765

766

767

768

769

770

771

772

773

774

775

Mohandas A, Cheng TC, and Cheng JB. 1985. Mechanism of lysosomal enzyme release from Mercenaria mercenaria granulocytes: A scanning electron microscope study. Journal of Invertebrate Pathology 46:189-197.

$\mathrm{Mu}$ H, Sun J, Heras H, Chu KH, and Qiu J-W. 2017. An integrated proteomic and transcriptomic analysis of perivitelline fluid proteins in a freshwater gastropod laying aerial eggs. Journal of Proteomics 155:22-30.

Nakao T. 1975. The fine structure and innervation of gill lamellae in Anodonta. Cell and Tissue Research 157:239-254.

Nicaise G. 1973. The gliointerstitial system of molluscs. International Review of Cytology. Academic Press: Elsevier, 251-332.

Nuwayhid M, Davies PS, and Elder H. 1978. Gill structure in the common limpet Patella vulgata. Journal of the Marine Biological Association of the United Kingdom 58:817823.

Ottaviani E. 1991. Tissue distribution and levels of natural and induced serum lysozyme immunoreactive molecules in a freshwater snail. Tissue and Cell 23:317-324.

Pickett JA, and Edwardson JM. 2006. Compound exocytosis: mechanisms and functional significance. Traffic 7:109-116.

Ponder WF, and Lindberg DR. 1997. Towards a phylogeny of gastropod molluscs: an analysis using morphological characters. Zoological Journal of the Linnean Society 119:83-265.

Prashad B. 1925. Anatomy of the common Indian apple-snail, Pila globosa. Memoirs of the Indian Museum 8:91-154.

Ranjah A. 1942. The embryology of the Indian apple-snail, Pila globosa (Swainson) (Mollusca, Gastropoda). Records of the Indian Museum 44:217-322.

Rebelo MdF, Figueiredo EdS, Mariante RM, Nóbrega A, de Barros CM, and Allodi S. 2013. New insights from the oyster Crassostrea rhizophorae on bivalve circulating hemocytes. PLoS ONE 8:e57384.

Ridewood WG. 1903. On the structure of the gills of the Lamellibranchia. Philosophical Transactions of the Royal Society of London 195:147-284.

Rodriguez C, Prieto GI, Vega IA, and Castro-Vazquez A. 2018. Assessment of the kidney and lung as immune barriers and hematopoietic sites in the invasive apple snail Pomacea canaliculata. PeerJ 6:e5789.

Ruthensteiner B. 1997. Homology of the pallial and pulmonary cavity of gastropods. Journal of Molluscan Studies 63:353-367.

Ruthensteiner B, and HEß M. 2008. Embedding 3D models of biological specimens in PDF publications. Microscopy Research and Technique 71:778-786.

Salvini-Plawen L, and Haszprunar G. 1987. The Vetigastropoda and the systematics of streptoneurous Gastropoda (Mollusca). Journal of Zoology 211:747-770.

Semper K. 1881. Animal life as affected by the natural conditions of existence. New York: D. Appleton and Co.

Seuffert ME, and Martín PR. 2010. Dependence on aerial respiration and its influence on microdistribution in the invasive freshwater snail Pomacea canaliculata (Caenogastropoda, Ampullariidae). Biological Invasions 12:1695-1708.

Stein JL, Cary SC, Hessler RR, Vetter RD, Felbeck H, Ohta S, and Childress JJ. 1988. Chemoautotrophic symbiosis in a hydrothermal vent gastropod. The Biological Bulletin 174:373-378. 
776

777

778

779

780

781

782

783

784

785

786

787

788

789

790

791

792

793

794

795

796

797

798

799

800

801

802

803

804

805

806

Stern DL. 2013. The genetic causes of convergent evolution. Nature Reviews Genetics 14:751764.

Sun J, Mu H, Ip JCH, Li R, Xu T, Accorsi A, Sánchez Alvarado A, Ross E, Lan Y, CastroVazquez A, Vega IA, Heras H, Ituarte S, Bocxclaer Bv, Hayes KA, Cowie RH, Zhao Z, Zhang Y, Qian P-Y, and Qiu J-W. 2019. Signatures of divergence, invasiveness, and terrestrialization revealed by four apple snail genomes. Molecular Biology and Evolution msz084.

Taylor P, and Andrews EB. 1987. Tissue adenosine-triphosphatase activities of the gill and excretory system in mesogastropod molluscs in relation to osmoregulatory capacity. Comparative Biochemistry and Physiology Part A: Physiology 86:693-696.

Ueshima E, and Yusa Y. 2015. Antipredator behaviour in response to single or combined predator cues in the apple snail Pomacea canaliculata. Journal of Molluscan Studies 81:51-57.

Vega IA, Damborenea M, Gamarra-Luques C, Koch E, Cueto J, and Castro-Vazquez A. 2006. Facultative and obligate symbiotic associations of Pomacea canaliculata (Caenogastropoda, Ampullariidae). Biocell 30:367-375.

Wanichanon C, Laimek P, Linthong V, Sretarugsa P, Kruatrachue M, Upatham ES, Poomtong T, and Sobhon P. 2004. Histology of hypobranchial gland and gill of Haliotis asinina Linnaeus. Journal of Shellfish Research 23:1107-1113.

Wilson JM, and Laurent P. 2002. Fish gill morphology: inside out. Journal of Experimental Zoology 293:192-213.

Windoffer R, and Giere O. 1997. Symbiosis of the hydrothermal vent gastropod Ifremeria nautilei (Provannidae) with endobacteria-structural analyses and ecological considerations. The Biological Bulletin 193:381-392.

Yonge CM. 1947. The pallial organs in the aspidobranch Gastropoda and their evolution throughout the Mollusca. Philosophical Transactions of the Royal Society of London Series B, Biological Sciences 232:443-518.

Yu AS. 2017. Paracellular transport as a strategy for energy conservation by multicellular organisms? Tissue Barriers 5:2509-2518.

PeerJ reviewing PDF | (2019:01:34352:2:0:NEW 12 Jun 2019) 


\section{Figure 1}

The gill and the pallial complex.

(A) Diagram of the pallial cavity of a male animal, opened as indicated in the thumbnail sketch at the right lower corner. (B) Panoramic section of the single row of rather parallel leaflets of the monopectinate gill that hang from the gill's base, below the outer mantle; the approximate position of this section is indicated in the thumbnail sketch at the right lower corner. Haematoxylin-eosin. Scale bar represents $1 \mathrm{~mm}$. Abbreviations: abv, afferent branchial vessel; anu, anus; gil, gill; dig, digestive gland; epb, efferent pulmobranchial vessel; ime, inner mantle epithelium; kid, kidney; Ift, gill leaflets; Ing, lung; med, mantle edge; mth, mouth; npo, nephropore; ome, outer mantle epithelium; osp, osphradium; pec, penial complex; pes, penial sheath; pfo, pallial fold; pne, pneumostome; pod, foot; rnl, right nuchal lobe; prc, pericardium; pro, prostate; sip, siphon; ten, tentacle; tes, testis; urt, ureter; vap, ventral afferent pulmonary vessel.
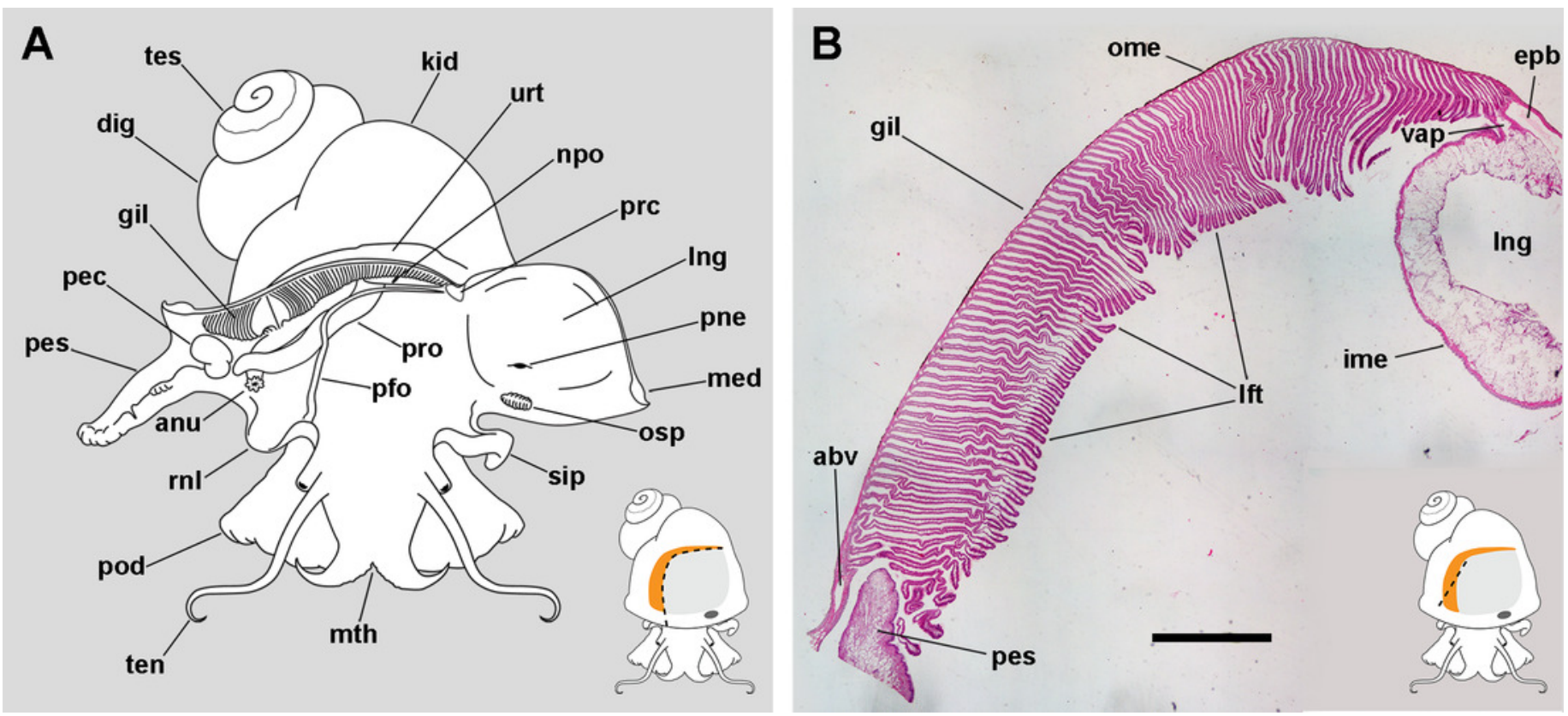


\section{Figure 2}

Computerised 3D rendering of the blood system of the gill.

(A) Dorsal view of the pallial complex. The gill (orange) occupies the right and posterior portion of the roof of the pallial cavity, bordering the lung (which is collapsed, see Methods) and the ureter. (B) Lateral view of a single gill leaflet. (C) The gill's blood supply; three gill leaflets are indicated by asterisks. (D) Blood sinuses in a single gill leaflet. (E) Diagram of the proposed blood flow to and from the gill. (F) Diagram of proposed blood flow within a gill leaflet. Scale bars represent: (A and C) 1 mm; (B and D) $500 \mu \mathrm{m}$. Abbreviations: abv, afferent branchial vessel; apv, afferent pulmonary vessel; aur, auricle; bls, basal leaflet sinus; gil, gill; epb, efferent pulmobranchial vessel; euv, efferent ureteral vessel (=efferent renal vein); Ifs, laminar leaflet sinus; Ift, gill leaflet; Ing, lung; med, mantle edge; mls, marginal leaflet sinus; npo, nephropore; osp, osphradium; pne, pneumostome; rct, rectum; rps, right pallial sinus; rsi, rectal sinus; urt, ureter; vap, ventral afferent pulmonary vessel. 
A

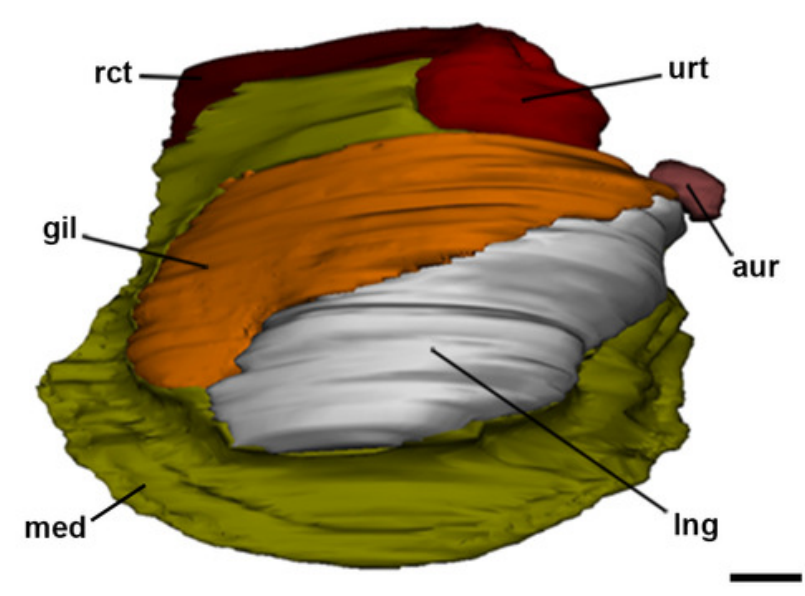

C

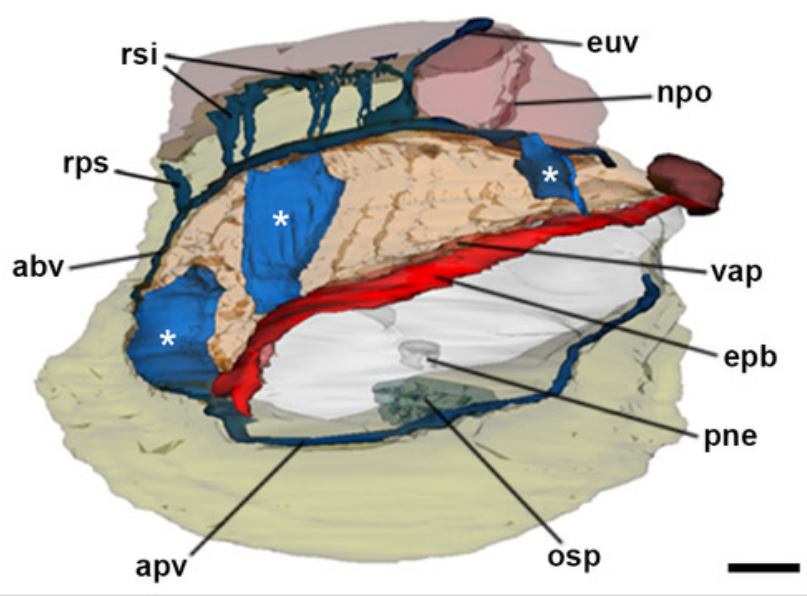

E

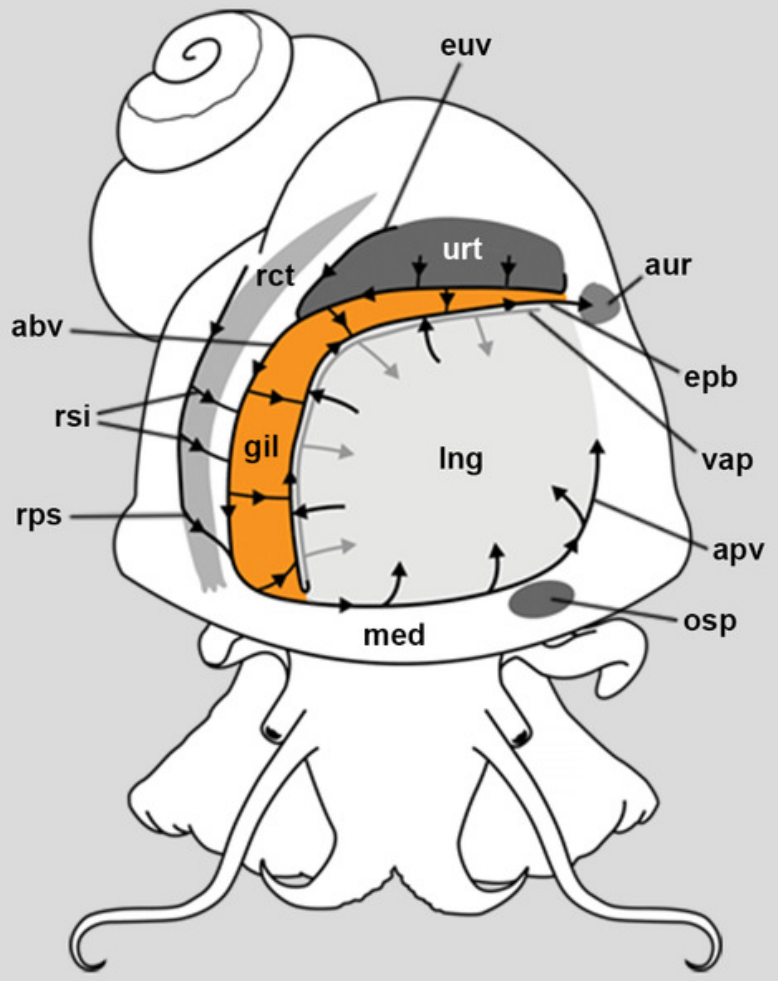

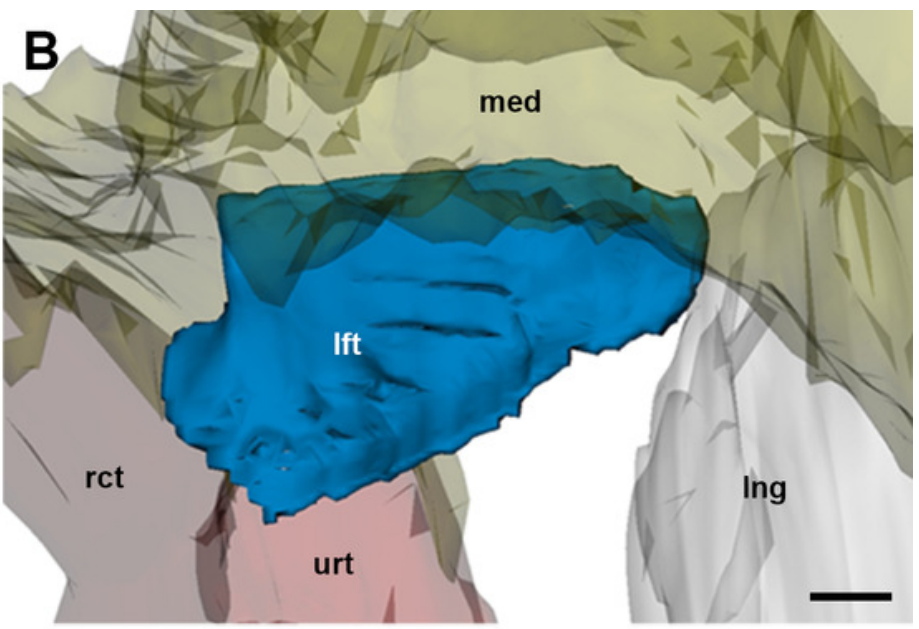

D

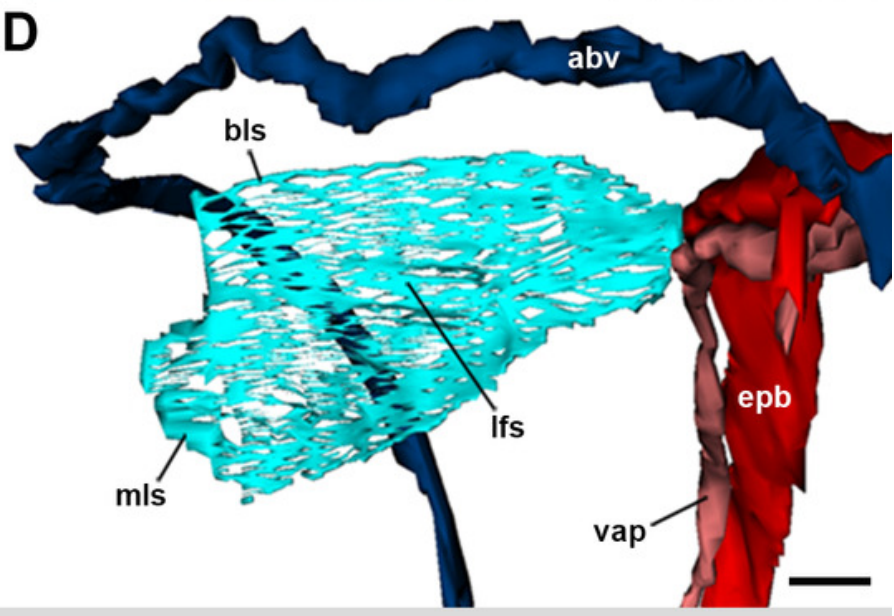

$\mathbf{F}$

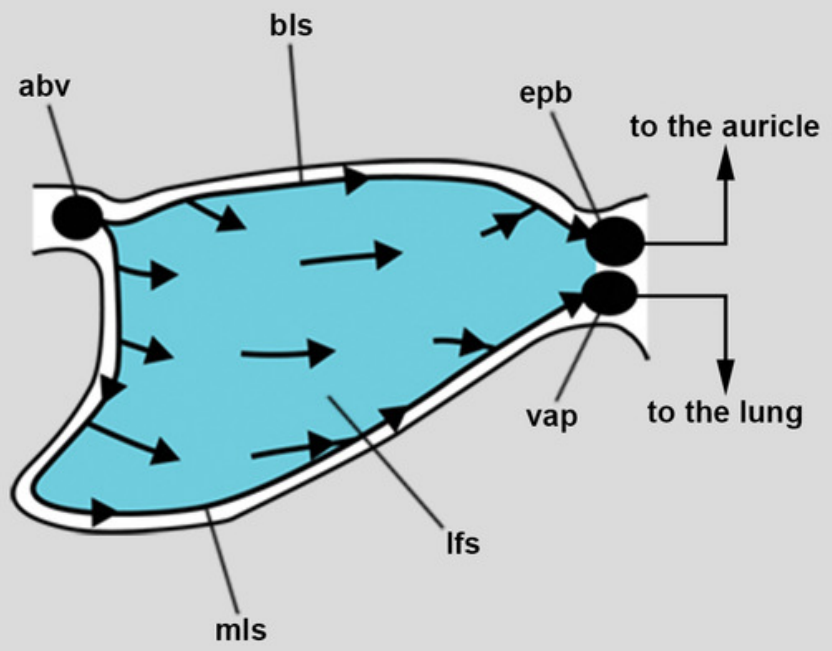




\section{Figure 3}

Gill innervation.

(A) Diagram showing the major ganglia (grey), the nerves, and the accessory ganglia supplying branchial innervation. The gill is innervated from the supraoesophageal ganglion by branches of the branchial nerve (pink). The branchial base nerve originates in the accessory visceral ganglion (violet). The copulatory ganglion may also contribute to branchial innervation (green). (B) Diagram of nerves within each gill leaflet and presumptive origin of the fine innervation (dashed lines). (C) Panoramic section of the gill, showing the branchial base nerve lying alongside the afferent branchial vessel. (D) Detail of the penial complex, showing the copulatory ganglion in the proximity of the branchial base nerve. (E) Detail of the gill base showing the branchial base nerve and the afferent branchial vessel. (F) Detail showing the branchial base nerve in the proximity of the efferent ureteral vessel. Haematoxylin-eosin; panels D-F correspond to sections adjacent to that in panel C. Scale bars represent: (C) $1 \mathrm{~cm}$; (D) $1 \mathrm{~mm}$; (E-F) $500 \mu \mathrm{m}$. Abbreviations: abv, afferent branchial vessel; avg, accessory visceral ganglion; bbn, branchial base nerve; brn, branchial nerve; cog, copulatory ganglion; euv, efferent ureteral vessel (=efferent renal vein); Ifn, leaflet nerve; Ift, gill leaflet; ome, outer mantle epithelium; osg, osphradial ganglion; pec, penial complex; pes, penial sheath; rpg, right pleural ganglion; rps, right pallial sinus; spg, supraoesophageal ganglion; svl, supraoesophageal portion of the visceral loop; urt, ureter; vig, visceral ganglion. 


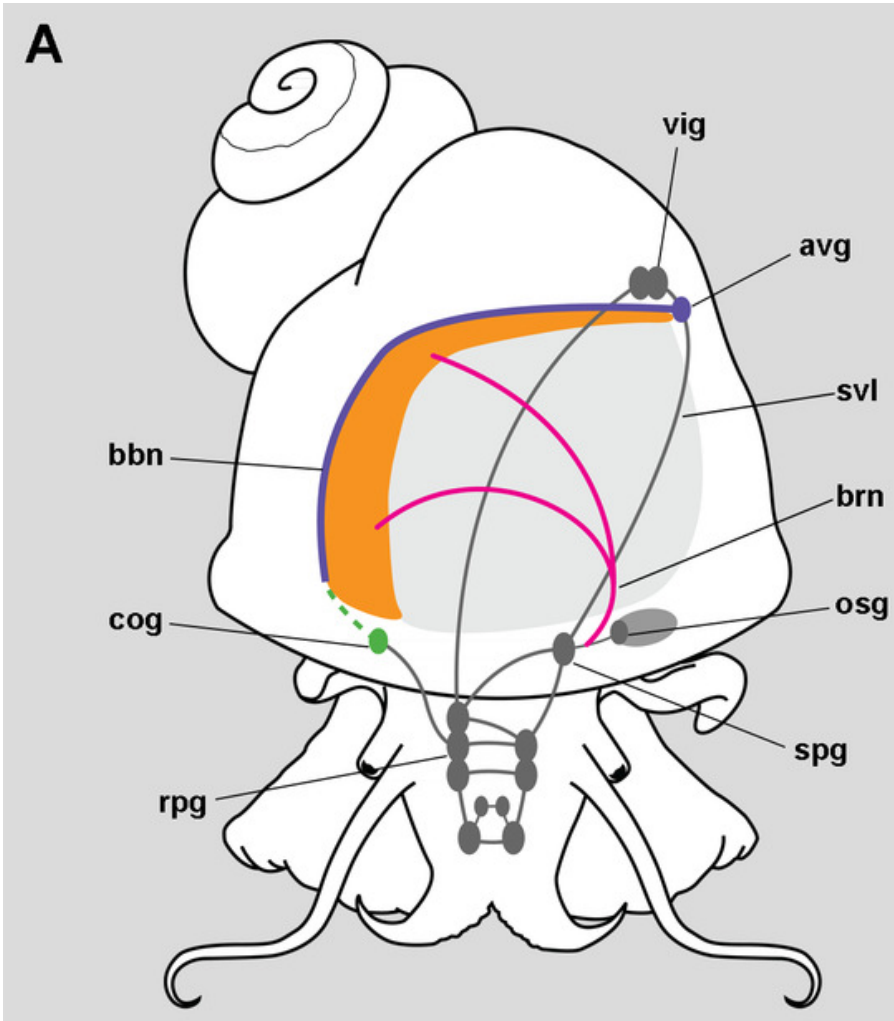

B

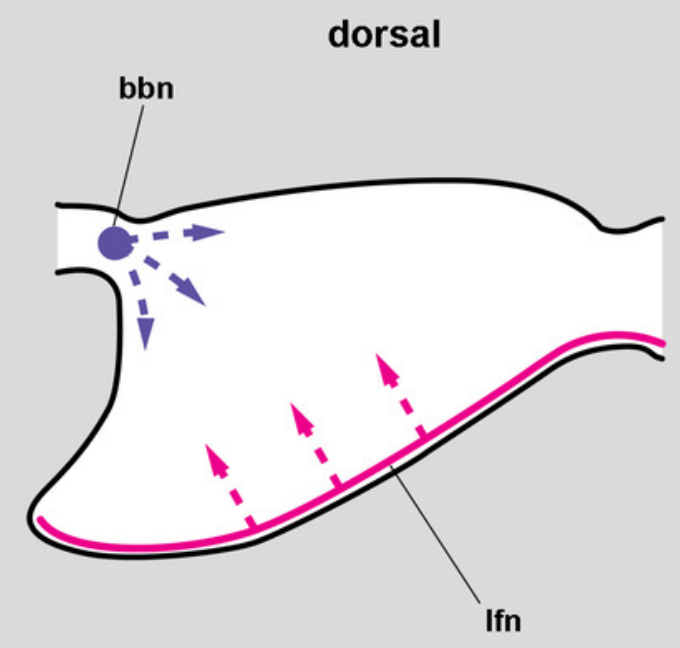

ventral

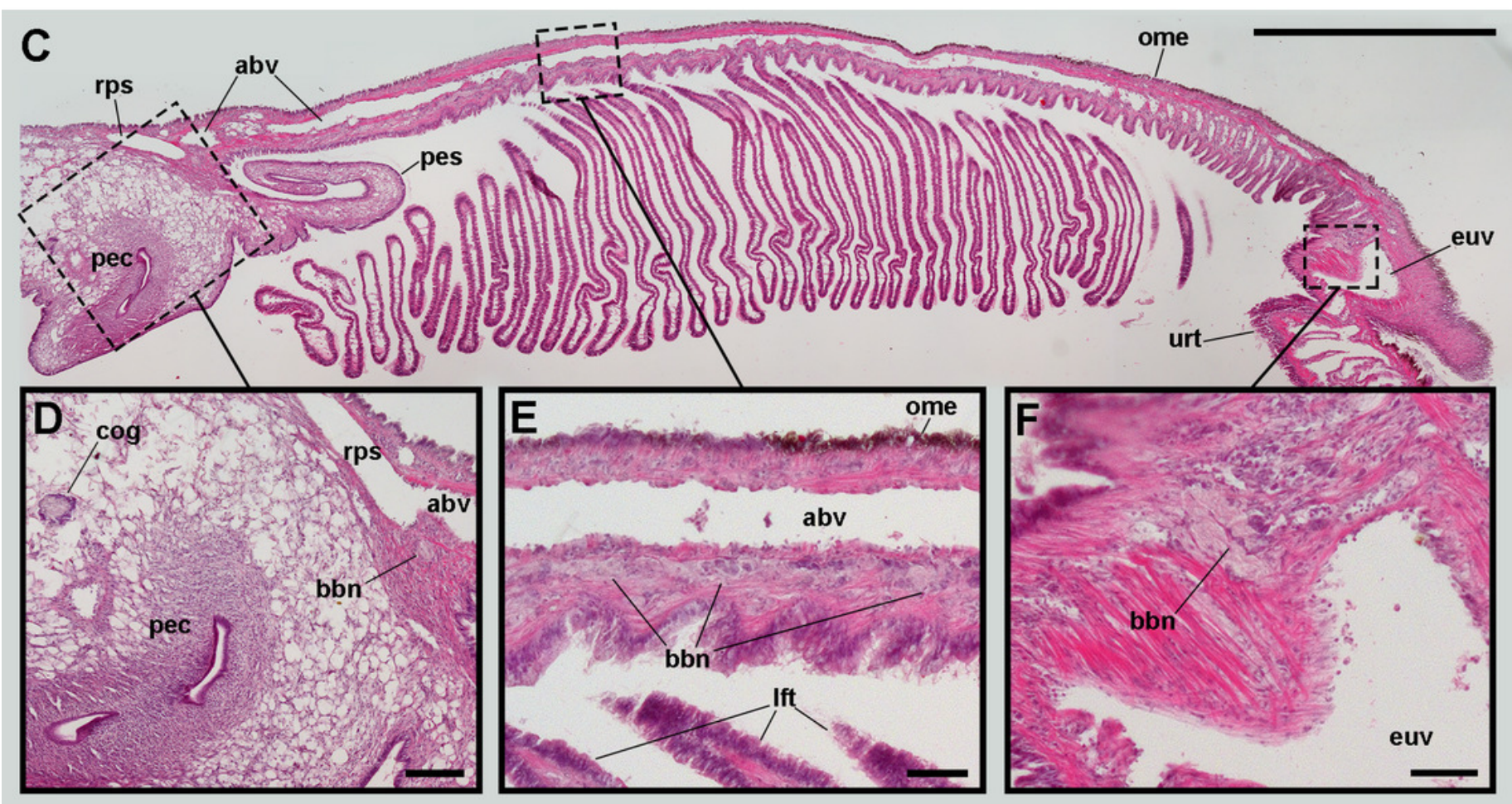




\section{Figure 4}

The gill leaflets and their regions (light microscopy).

(A) Diagram of the four regions of the gill leaflets, which differ in the cell types of its covering epithelium and underlying structures. (B-C) Region I occupies the largest part of the leaflet, while regions II-IV. (D-E) constitute its thickened margin. Scale bars represent $20 \mu \mathrm{m}$. Haematoxylin-eosin or toluidine blue. Abbreviations: bls, basal leaflet sinus; cil, cilia; fml, fibromuscular layer; gra, granulocytes; ics, intercellular spaces; Ifn, leaflet nerve; Ifs, laminar leaflet sinus; Imf, bundle of longitudinal muscle fibres; mls, marginal leaflet sinus; nuc, epithelial cell nuclei; ome, outer mantle epithelium; sec, secretory cells; tra, trabeculae.
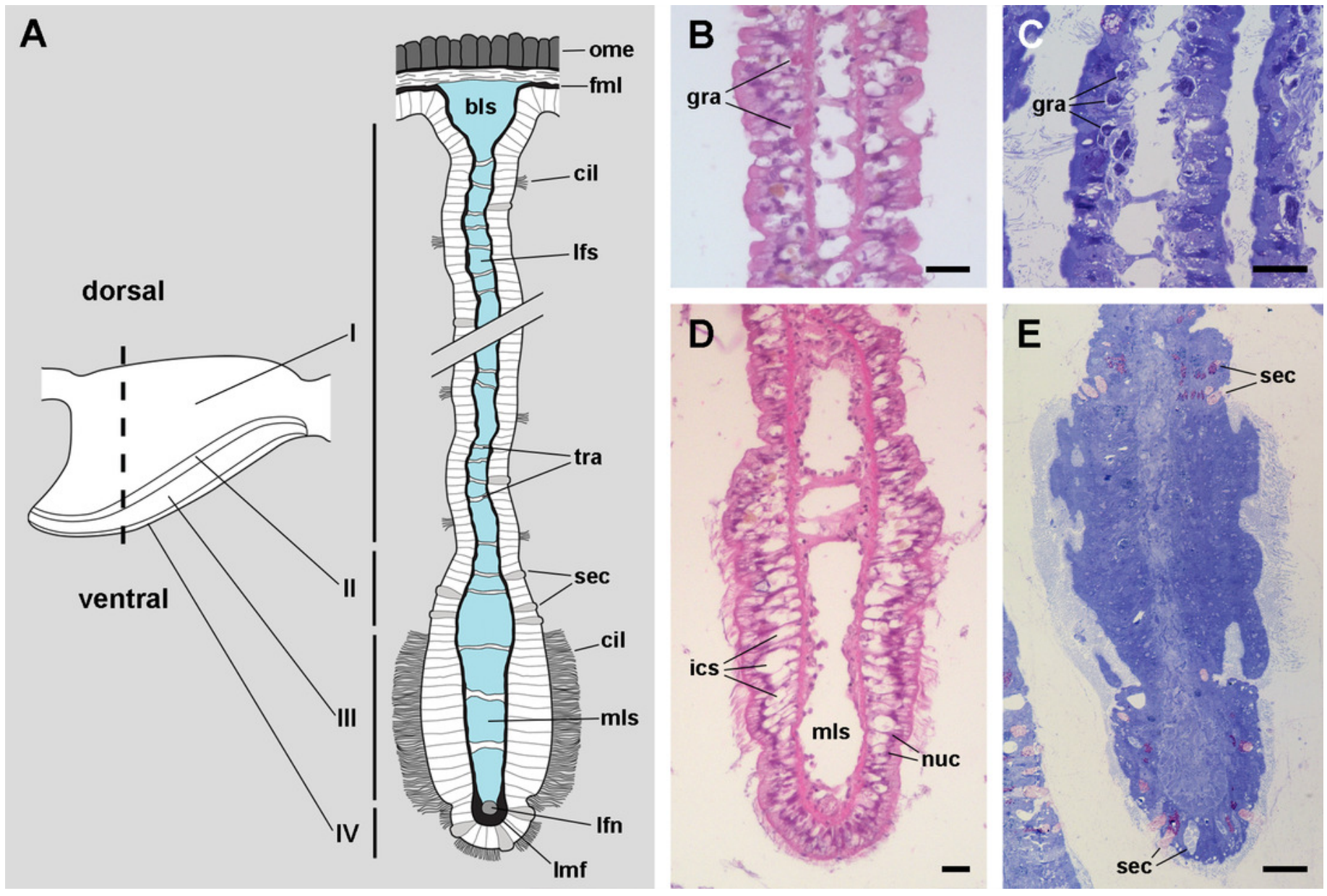


\section{Figure 5}

Apical specialisations on the gill surface (scanning electron microscopy).

(A) Three adjacent gill leaflets, two of them sectioned to show the laminar leaflet sinus.

Regions described in Figure 4A are indicated in the thumbnail sketch. (B) Region I exhibiting the cilia of $\alpha$-cells and the ramified microvilli of $\beta$-cells. (C) Region III exhibiting the long cilia of $\mathrm{C} 2$ cells with the characteristic membrane blebs. (D) Region IV exhibiting bundles of the short cilia of $\mathrm{Cl}$ cells, and interspersed spaces showing the microvilli of $\alpha$-cells. (E) A cut through region I of a gill leaflet, showing the laminar leaflet sinus, the trabeculae traversing it, and the covering leaflet epithelia showing $\alpha$-cells, $\beta$-cells and $\mathrm{C} 1$ cells. Scale bars represent: (A) $200 \mu \mathrm{m}$; (B) $10 \mu \mathrm{m}$; (C-E) $2 \mu \mathrm{m}$. Abbreviations: $\alpha$-c, $\alpha$-cells; $\beta$-c, $\beta$-cells; C1, short cilia cells; Ifs, laminar leaflet sinus; mbl, membrane blebs on the long cilia; tra, trabeculae.

*Note: Auto Gamma Correction was used for the image. This only affects the reviewing manuscript. See original source image if needed for review. 

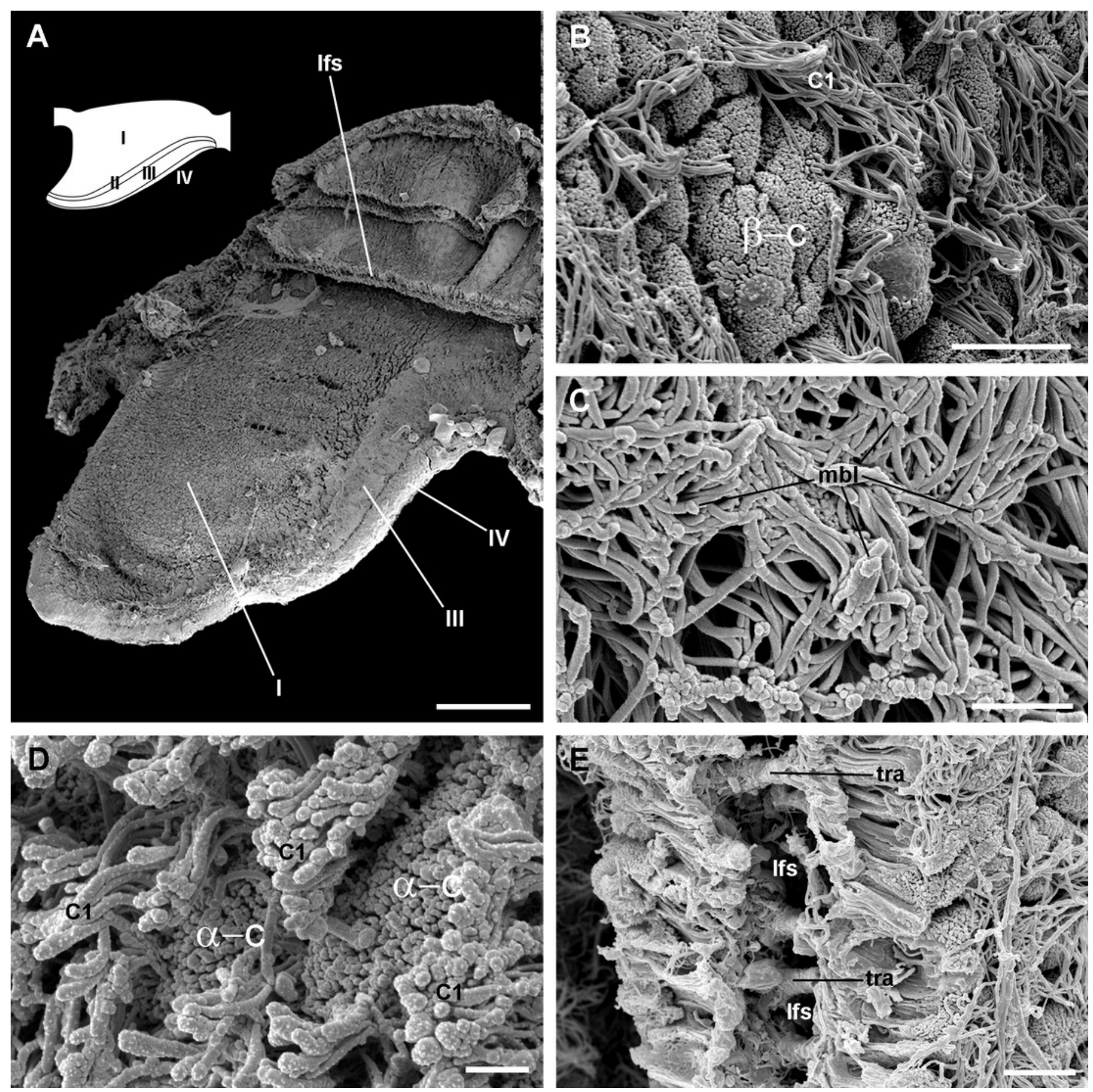


\section{Figure 6}

The muscular bundle and the leaflet nerve (light and electron microscopy).

(A) Margin of a gill leaflet showing the covering epithelium, the muscular bundle and the leaflet nerve. Toluidine blue. (B) Razor blade cuts of three gill leaflets showing the muscular bundles as well-defined units beneath the covering epithelium. Scanning electron microscopy. (C) Tangential section of the leaflet border showing two muscular cells pertaining to the muscular bundle and a fairly longitudinal section of the leaflet nerve. Transmission electron microscopy. (D) A high magnification of the leaflet nerve showing tightly packed neurites containing neurotubules, clear vesicles or electron-dense granules of different sizes. (E) A section through the muscular bundle showing large muscle fibres containing myofibrils, and that are embedded in a collagen matrix where glial processes are found. Arrowheads indicate the basal lamina of the covering epithelium. Scale bars represent: (A) $10 \mu \mathrm{m}$; (B) $25 \mu \mathrm{m}$; (C-D) $1 \mu \mathrm{m}$; (E) $250 \mathrm{~nm}$. Abbreviations: C1, short cilia cells; col, collagen matrix; gcp, glial cell process; gra, granulocyte; Ifn, leaflet nerve; Imf, bundle of longitudinal muscle fibres; msc, muscle cell; mye, myeloid body; S1, metachromatic secretory cells; S2, orthochromatic secretory cells. 

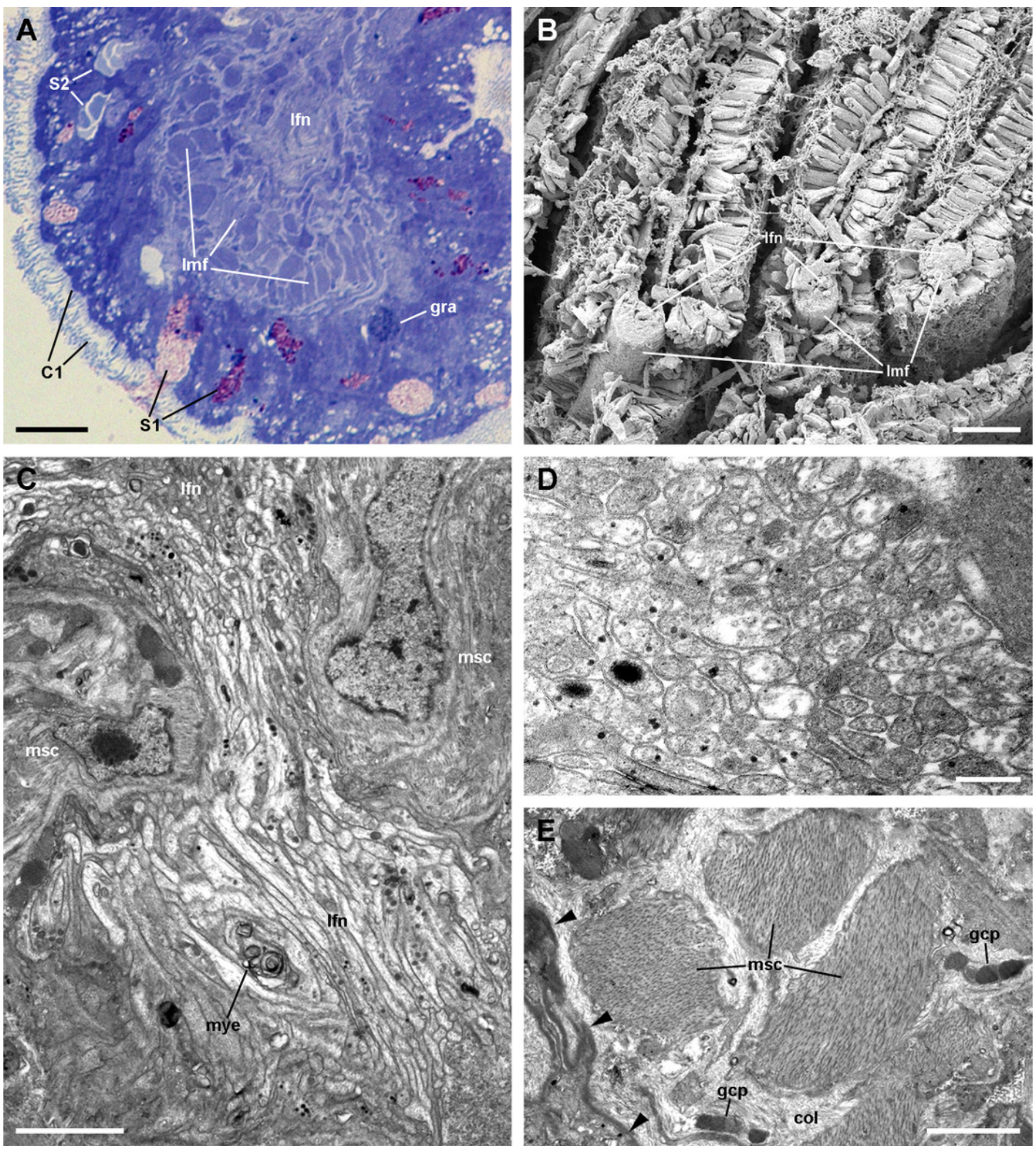


\section{Figure 7}

Mitochondria-rich cells in region I of the gill leaflets (diagram).

The two main cell types found in region I are $\alpha$ - and $\beta$-cells. In addition, granulocytes occur within epithelial intercellular spaces. Abbreviations: adh, adherent junction; $\alpha-c$, alpha-cell; $\beta$ c, beta-cell; bla, basal lamina; dtu, bundles of electron-dense tubules; gra, granulocyte; grn, R granules; fgr, fibrogranular material; gly, glycogen deposit; icc, intercellular canaliculi; ics, intercellular space; mlb, multilamellar bodies; mvb, multivesicular bodies; mvi, microvilli; mye, myeloid bodies; neu, neurite bundle; sep, septate junction; tep, thin epithelial projections; tub, tubular system.

*Note: Auto Gamma Correction was used for the image. This only affects the reviewing manuscript. See original source image if needed for review.

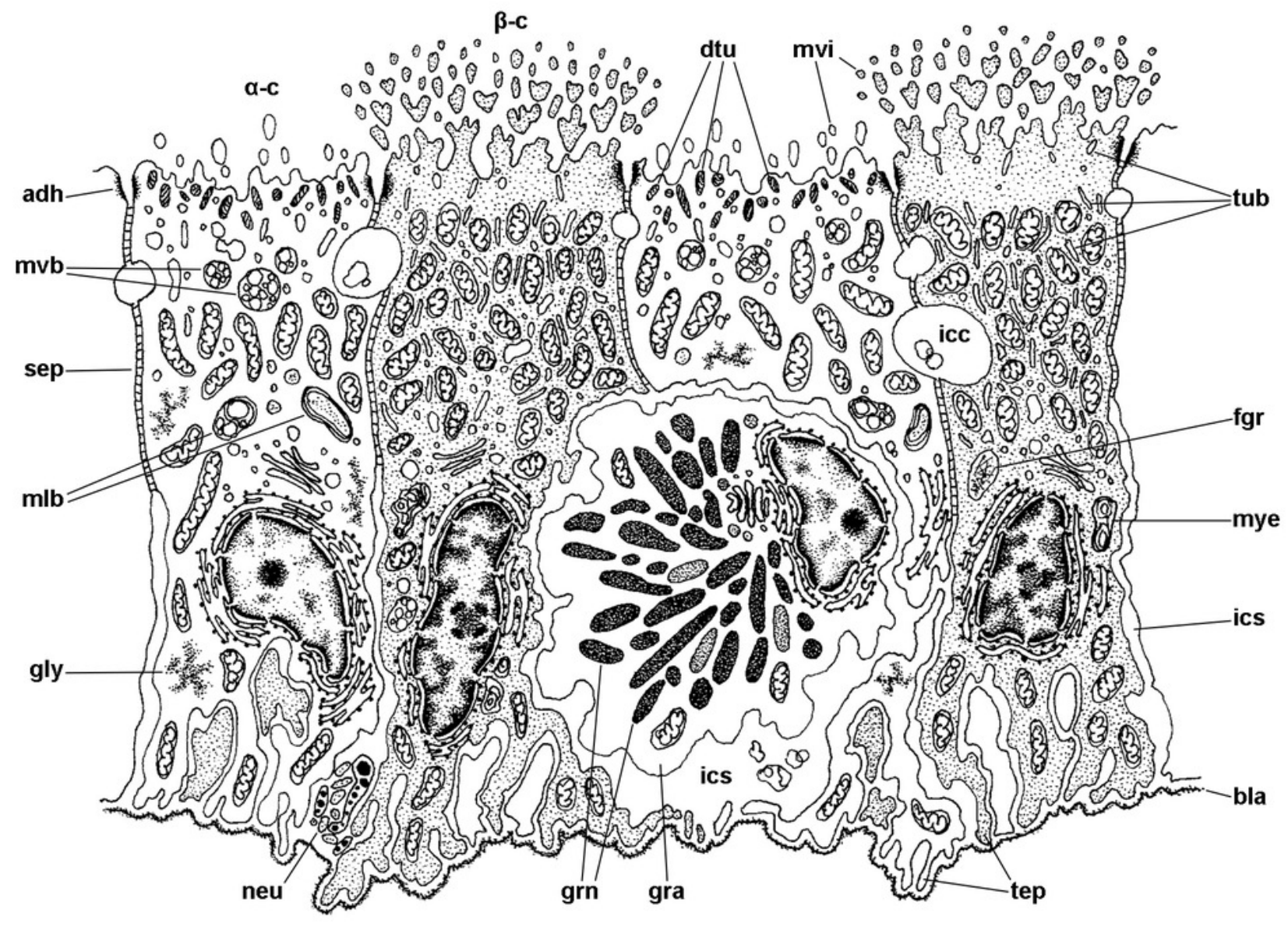




\section{Figure 8}

Mitochondria-rich cells in region I of the gill leaflets (transmission electron microscopy).

(A) Alpha-cells exhibit few and short microvilli, numerous and long mitochondria with welldefined cristae, and glycogen deposits. Their nuclei are euchromatic with conspicuous nucleoli. (B) Apically, $\alpha$-cells show numerous membrane-bound bundles of electron-dense tubules/filaments, and a well-developed vesicular system, including multivesicular bodies. (C) Multilamellar bodies and Golgi bodies are found close to the nucleus. (D) Contrasting with $\alpha$ cells, $\beta$-cells have numerous and ramified microvilli. These cells also have numerous tightlypacked mitochondria that fill almost all the cytoplasm. The nuclei are heterochromatic. $(E)$ Beta-cells show an extensive tubular system between the mitochondria. (F) A $\beta$-cell showing multivesicular bodies and presumptively degenerative bodies, such as myeloid bodies and fibrogranular material. Scale bars represent: (A) $1 \mu \mathrm{m}$; (B) $200 \mathrm{~nm}$; (C) $250 \mathrm{~nm}$; (D) $1 \mu \mathrm{m}$; (E) $500 \mathrm{~nm}$; (F) $250 \mathrm{~nm}$. Abbreviations: $\alpha-c$, alpha-cell; $\beta$-c, beta-cell; dtu, bundles of electrondense tubules; fgr, fibrogranular material; gly, glycogen deposit; gol, Golgi body; gra, granulocyte; icc, intercellular canaliculi; mit, mitochondria; mlb, multilamellar body; mvb, multivesicular body; mvi, microvilli; mye, myeloid body; nuc, cell nucleus; rer, rough endoplasmic reticulum; tep, thin epithelial projections; tub, tubular-vesicular system. 

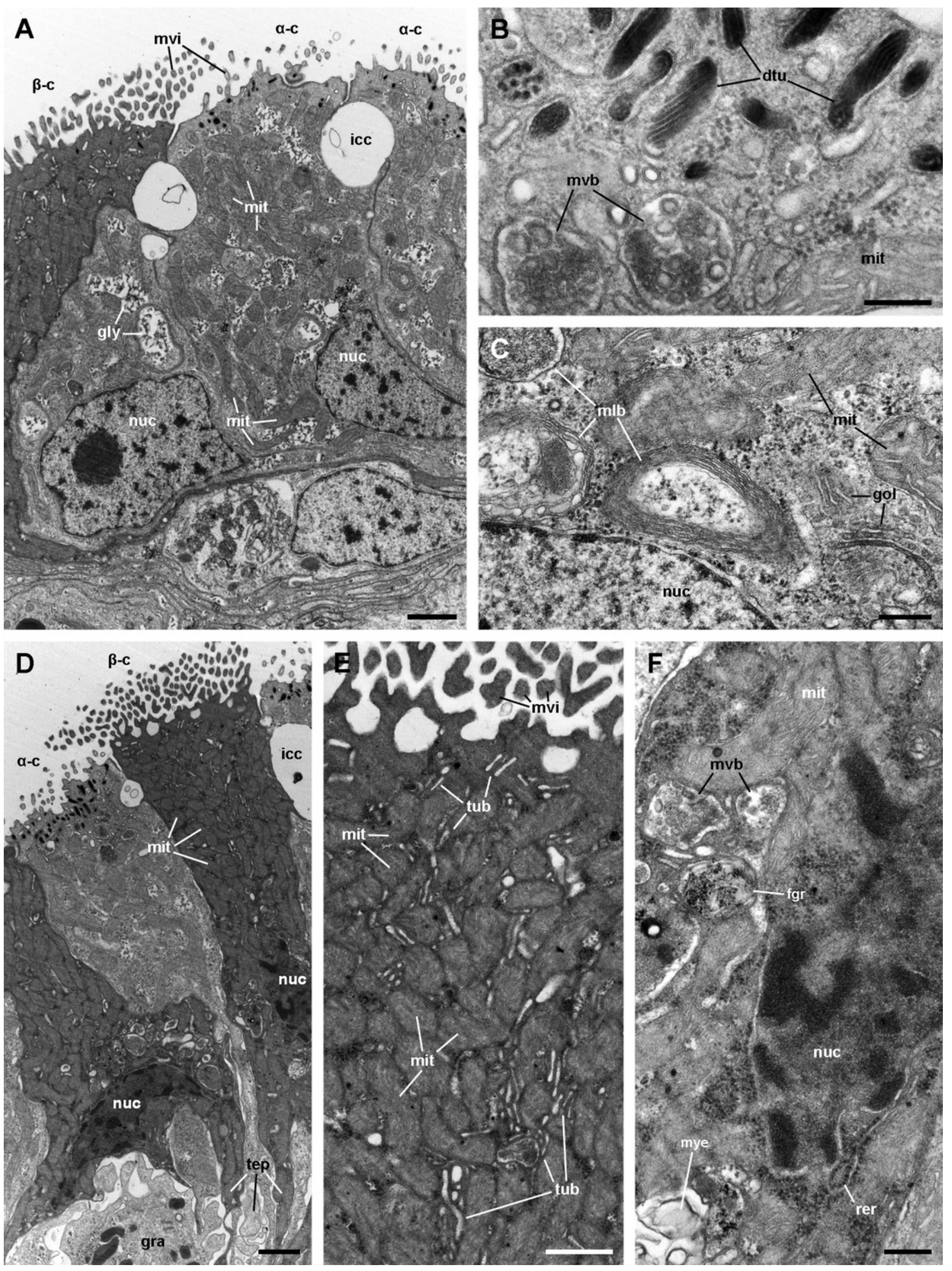


\section{Figure 9}

Structures associated with granulocytes in the basolateral domain of the gill epithelium (transmission electron microscopy).

(A) Labyrinth of thin cellular extensions projecting towards the collagen matrix of the underlying connective tissue, where sparse muscle fibres occur. Subepithelial and intraepithelial (arrows) neurite bundles with accompanying glial cells also occur. (B) A granulocyte in close proximity to the basal lamina occupies an enlarged intercellular space. Small intercellular spaces or canaliculi are also seen. (C) Discontinuities in the basal mesh of epithelial projections connect the intercellular spaces directly with the basal lamina, which shows interspersed electron dense thickenings (arrowheads). (D) Basolateral infoldings of an $\alpha$-cell, adjacent to a $\beta$-cell. Scale bars represent: (A-B) $2 \mu \mathrm{m}$; (C) $1 \mu \mathrm{m}$; (D) $500 \mathrm{~nm}$.

Abbreviations: bla, basal lamina; bsi, blood sinus; col, collagen matrix; gra, granulocyte; grn, R granule; icc, intercellular canaliculi; ics, intercellular space; msc, muscle cell; neu, neurite bundle; tep, thin epithelial projections. 

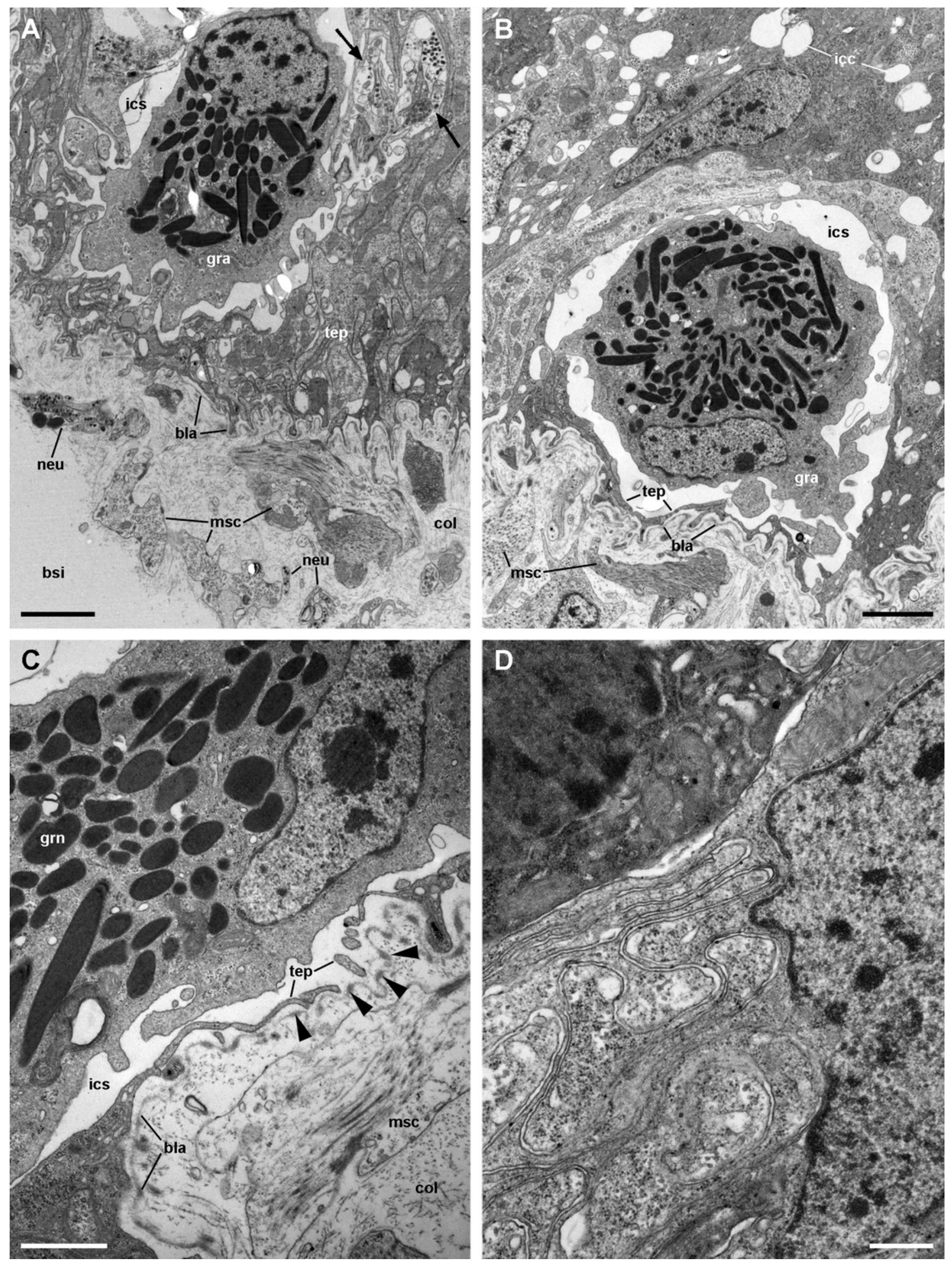


\section{Figure 10}

Long cilia cells (C2) in region III of the gill leaflets (transmission electron microscopy).

(A) Diagram. (B) C2 cells exhibit an electron dense cytoplasm with abundant rough endoplasmic reticulum and glycogen deposits. These cells rest on a thick and electron dense basal lamina (arrowheads). There are extensive intercellular spaces and smaller canaliculi, also seen under light microscopy (Figure 4D). (C) Transverse section of a cilium shows the typical 9+2 microtubule arrangement and membrane blebs (arrows). (D) Membrane-bound bundles of electron-dense tubules/filaments in the apical domain of a C2 cell. Scale bars represent: (B) $1 \mu \mathrm{m}$; (C) $50 \mathrm{~nm}$; (D) $250 \mathrm{~nm}$. Abbreviations: adh, adherent junction; bla, basal lamina; cil, cilia; dtu, bundles of electron-dense tubules; gly, glycogen deposit; icc, intercellular canaliculi; ics, intercellular space; msc, muscle cell; mtb, microtubules; mvi, microvilli; neu, neurite bundle; rer, rough endoplasmic reticulum; sep, septate junction; tep, thin epithelial projections. 

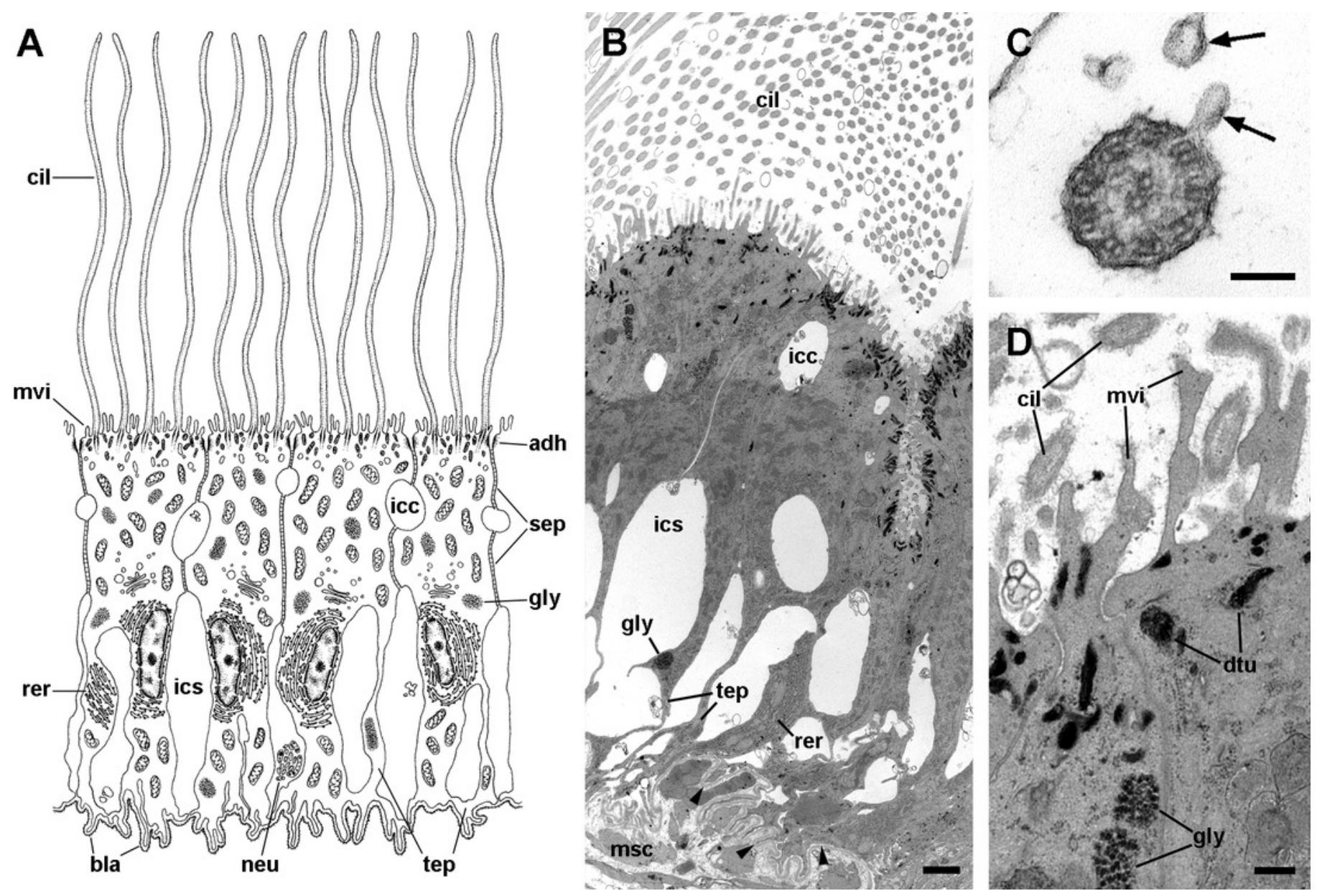


\section{Figure 11}

Ciliary (C1) and secretory (S1 and S2) cells in region IV of the gill leaflets (transmission electron microscopy).

(A) Diagram. (B) C1 cells exhibit a moderately electron-dense cytoplasm containing large dense-cored granules and a heterochromatic nucleus. Apically, there are finger-like microvilli and short cilia with membrane blebs. Glycogen deposits are also found. (C) An S1 cell showing granules above the nucleus, which contain an inner electron-dense mesh. (D) An S1 cell showing a large accumulation of granules with a looser electron-dense mesh, in the apex. (E) An S2 cell with the cytoplasm almost filled with vacuoles containing a microgranular substance of moderate electron density. Scale bars represent: (B) $1 \mu \mathrm{m}$; (C) $500 \mathrm{~nm}$; (D-E) 1 $\mu \mathrm{m}$. Abbreviations: adh, adherent junction; bla, basal lamina; cil, cilia; dcg, dense-core granules; dtu, bundles of electron-dense tubules; gly, glycogen deposit; icc, intercellular canaliculi; ics, intercellular space; mug, mucinogen granules; mvb, multivesicular body; mvi, microvilli; neu, neurite bundle; nuc, cell nucleus; sep, septate junction; tep, thin epithelial projections; vac, vacuoles. 

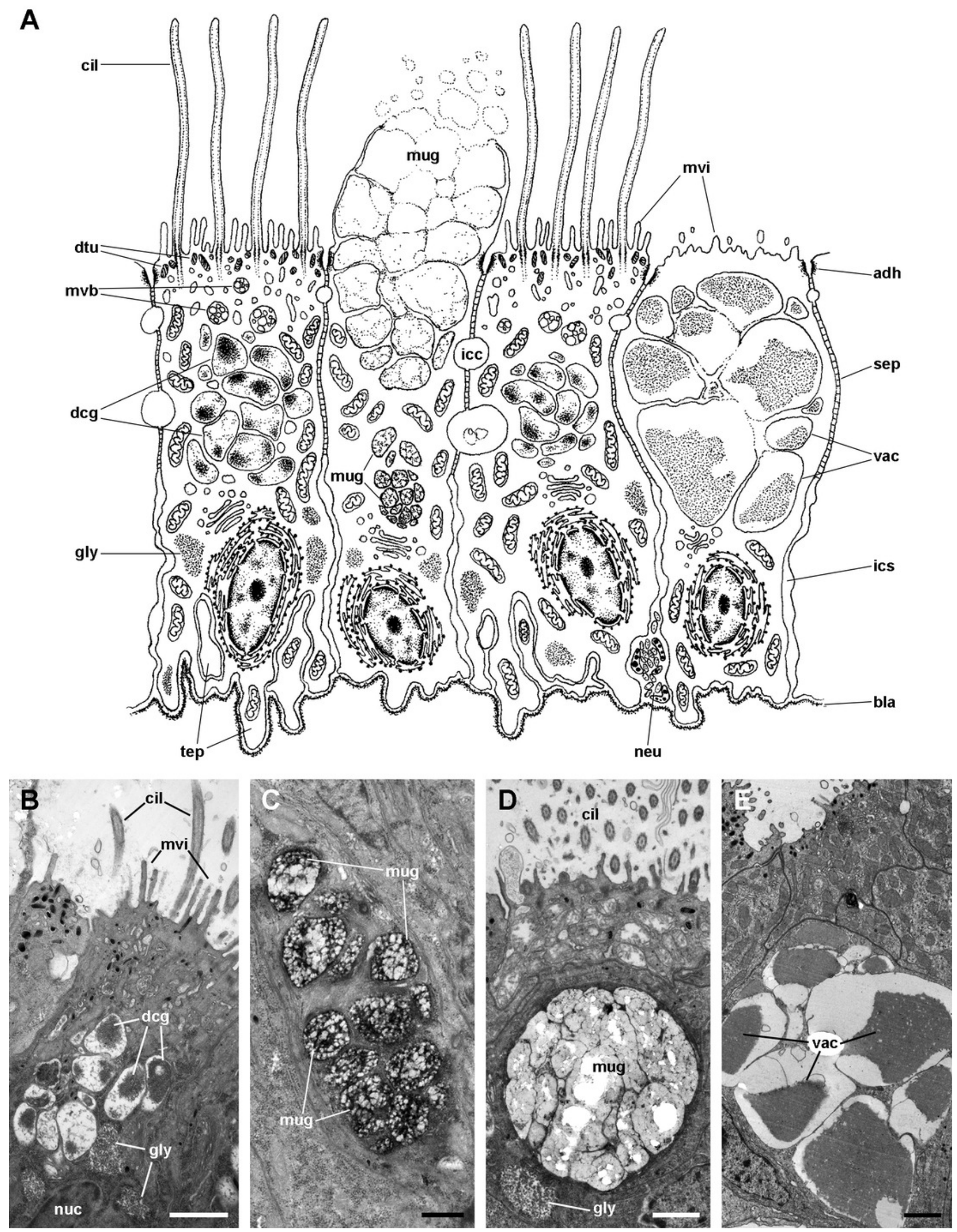


\section{Figure 12}

Cell junctions in the gill epithelium (transmission electron microscopy).

(A) Apical adherent junction followed by a short septate junction and an intercellular canaliculum with some content. (B) A septate junction. (C) Widening of an intercellular space below the septate junction. Scale bars represent $200 \mathrm{~nm}$. Abbreviations: adh, adherent junction; dtu, bundles of electron-dense tubule; icc, intercellular canaliculi; ics, intercellular space; mit, mitochondrion; sep, septate junction; tub, tubular system. 

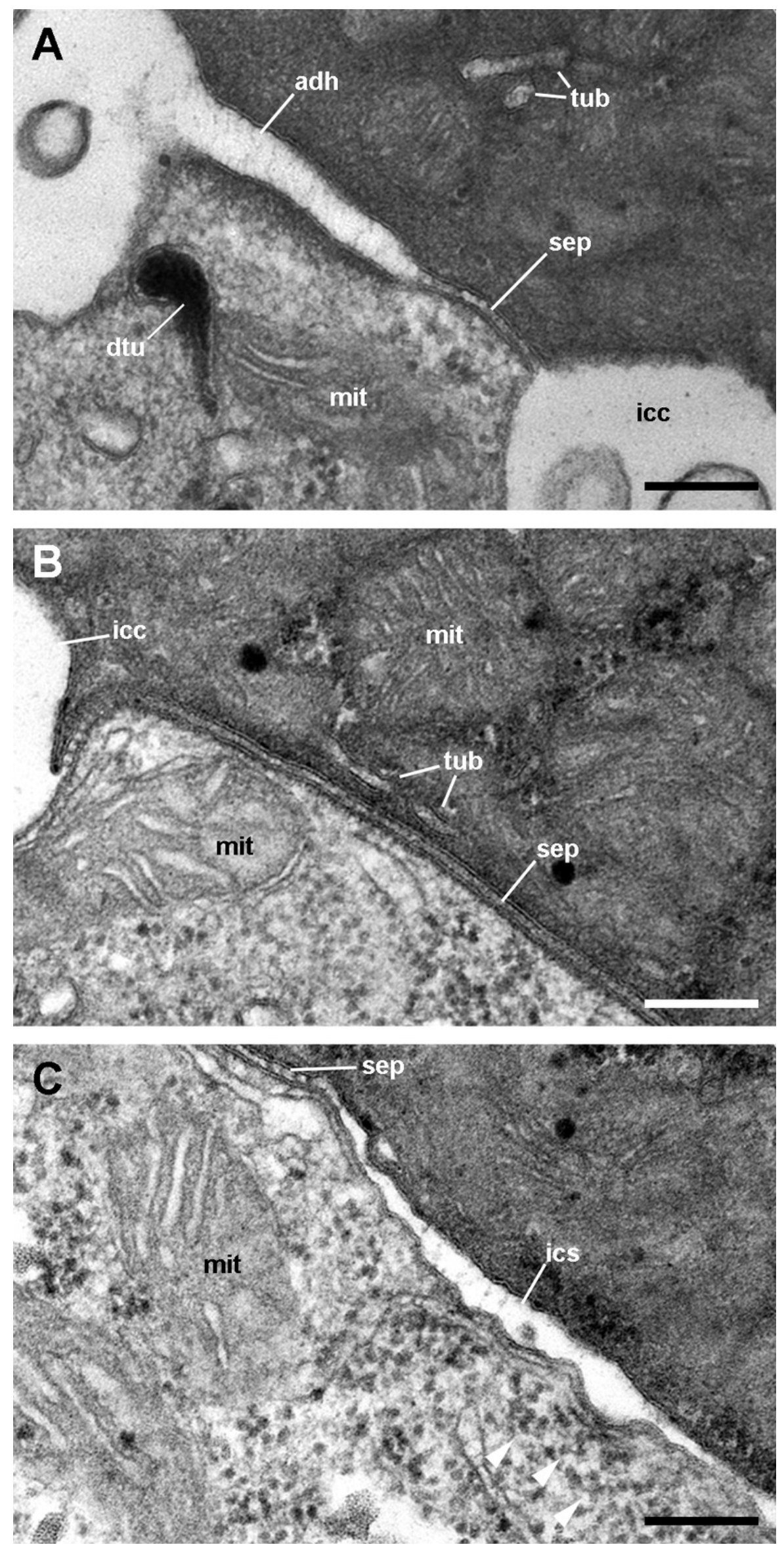

Peer) reviewing PDF | (2019:01:34352:2:0:NEW 12 Jun 2019) 


\section{Figure 13}

Fibromuscular tissue and fine innervation of the gill leaflets (transmission electron microscopy).

(A) Overview of the basal domain of epithelial cells, together with a granulocyte in contact with the basal lamina (arrowheads). The underlying tissue exhibits a neurite/glial bundle and trabecular fibromuscular cells with inner myofibrils and electron-dense anchoring junctions with the collagen matrix and the basal lamina. Also notice some intraepithelial neurites (white arrows). (B) Detail of anchoring junctions showing the external brush-like plaque and the internal amorphous electron-dense layer. (C) Detail of a neurite bundle showing neurites associated with glial cells' processes containing granules of different sizes and electron density. Glial cells, or rarely uncovered neurite bundles, are in contact with muscle fibres or trabeculae. Scale bars represent: (A) $1 \mu \mathrm{m}$; (B) $500 \mathrm{~nm}$; (C) $500 \mathrm{~nm}$. Abbreviations: anc; anchoring junction; col, collagen matrix; gcp, glial cell process; gra, granulocyte; ics, intercellular space; mit, mitochondria; msc, muscle cells; myo, myofibrils; nee, presumptive nerve endings; neu, neurite bundles; tep, thin epithelial projection. 

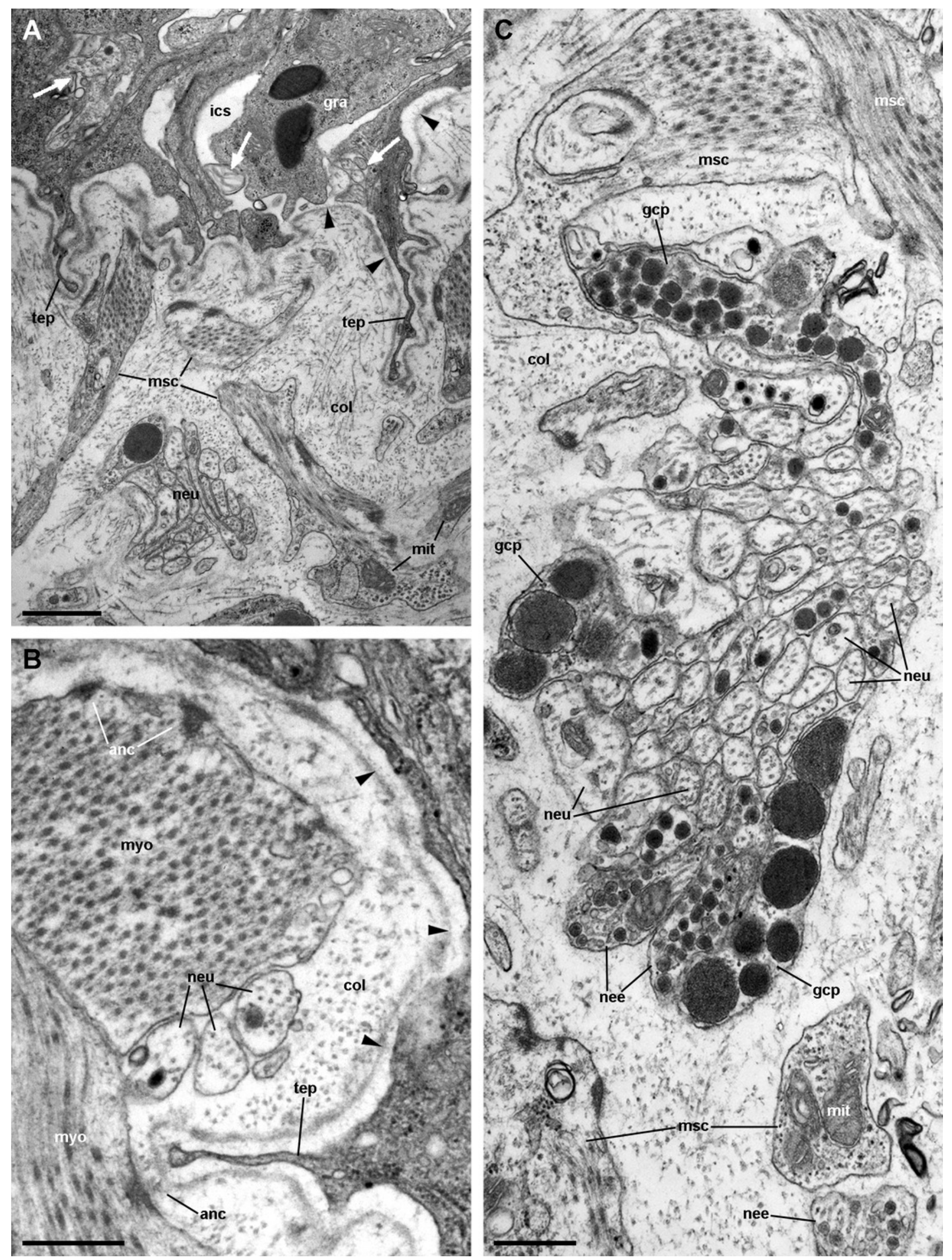


\section{Table 1 (on next page)}

Cell types and other features of the gill leaflet regions. 


\begin{tabular}{|c|c|c|c|c|c|}
\hline \multirow[b]{2}{*}{ Region } & \multicolumn{3}{|c|}{ Epithelial cell types } & \multirow[b]{2}{*}{$\begin{array}{l}\text { Epithelial } \\
\text { intercellular } \\
\text { spaces }\end{array}$} & \multirow[b]{2}{*}{ Underlying tissues } \\
\hline & $\begin{array}{l}\text { Microvillar } \\
\text { cells }\end{array}$ & $\begin{array}{l}\text { Ciliary } \\
\text { cells }\end{array}$ & $\begin{array}{l}\text { Secretory } \\
\text { cells }\end{array}$ & & \\
\hline $\mathbf{I}$ & $\alpha$ and $\beta$ & C1 & $\begin{array}{c}\text { S1 and S2 } \\
\text { (scarce) }\end{array}$ & $\begin{array}{c}\text { Extensive spaces, } \\
\text { with numerous } \\
\text { granulocytes }\end{array}$ & $\begin{array}{l}\text { Thin basal lamina } \\
\text { Loose fibromuscular } \\
\text { tissue } \\
\text { Thin trabeculae cross } \\
\text { the laminar leaflet } \\
\text { sinus }\end{array}$ \\
\hline II & $\alpha$ & None & $\begin{array}{l}\text { S1 and S2 } \\
\text { (abundant) }\end{array}$ & $\begin{array}{l}\text { Narrow spaces, } \\
\text { scarce } \\
\text { granulocytes }\end{array}$ & $\begin{array}{l}\text { Thick basal lamina } \\
\text { Dense fibromuscular } \\
\text { tissue } \\
\text { Thin trabeculae cross } \\
\text { the marginal leaflet } \\
\text { sinus }\end{array}$ \\
\hline III & None & $\mathrm{C} 2$ & None & $\begin{array}{c}\text { Extensive spaces, } \\
\text { scarce } \\
\text { granulocytes }\end{array}$ & $\begin{array}{l}\text { Thick basal lamina } \\
\text { Dense fibromuscular } \\
\text { tissue } \\
\text { Thick trabeculae cross } \\
\text { the marginal leaflet } \\
\text { sinus }\end{array}$ \\
\hline IV & $\alpha$ & C1 & $\begin{array}{l}\text { Abundant S1 } \\
\text { and S2 }\end{array}$ & $\begin{array}{l}\text { Narrow spaces, } \\
\text { scarce } \\
\text { granulocytes }\end{array}$ & $\begin{array}{c}\text { Thick basal lamina } \\
\text { Muscular bundle } \\
\text { Leaflet nerve }\end{array}$ \\
\hline
\end{tabular}

2 Abbreviations: $\alpha, \alpha$-cells; $\beta, \beta$-cells; C1, short cilia cells; C2, long cilia cells; $S 1$, metachromatic secretory 3 cells; S2, orthochromatic secretory cells. 


\section{Table 2(on next page)}

Features of the cell types in the gill epithelium of $P$. canaliculata. 


\begin{tabular}{|c|c|c|c|c|}
\hline $\begin{array}{l}\text { Cell } \\
\text { type }\end{array}$ & $\begin{array}{c}\text { Apical } \\
\text { specialisations }\end{array}$ & $\begin{array}{l}\text { Nucleus and } \\
\text { cytoplasm }\end{array}$ & Endomembrane system & Other membrane-bound bodies \\
\hline$\alpha$ & $\begin{array}{l}\text { Few and short, } \\
\text { finger-like } \\
\text { microvilli }\end{array}$ & $\begin{array}{l}\text { Euchromatic } \\
\text { nucleus } \\
\text { Abundant, long } \\
\text { mitochondria }\end{array}$ & $\begin{array}{c}\text { Abundant RER } \\
\text { Golgi bodies } \\
\text { Vesicular system } \\
\text { Multivesicular bodies } \\
\text { Multilamellar bodies }\end{array}$ & $\begin{array}{l}\text { Bundles of electron-dense } \\
\text { tubules/filaments } \\
\text { Dense-cored granules } \\
\text { (in region IV only) }\end{array}$ \\
\hline$\beta$ & $\begin{array}{l}\text { Numerous and } \\
\text { long, ramified } \\
\text { microvilli }\end{array}$ & $\begin{array}{l}\text { Heterochromatic } \\
\text { nucleus } \\
\text { Tightly-packed, } \\
\text { short mitochondria }\end{array}$ & $\begin{array}{l}\text { Tubular system } \\
\text { Multivesicular bodies } \\
\text { Myeloid and } \\
\text { fibrogranular } \\
\text { bodies }\end{array}$ & $\begin{array}{l}\text { Few and small bundles of electron- } \\
\text { dense tubules/filaments }\end{array}$ \\
\hline C1 & $\begin{array}{l}\text { Short cilia with } \\
\text { membrane blebs } \\
\text { Short, finger-like } \\
\text { microvilli }\end{array}$ & $\begin{array}{l}\text { Heterochromatic } \\
\text { nucleus } \\
\text { Rather dark } \\
\text { cytoplasm }\end{array}$ & $\begin{array}{l}\text { Vesicular system } \\
\text { Multivesicular bodies }\end{array}$ & $\begin{array}{l}\text { Abundant and large dense-cored } \\
\text { granules } \\
\text { Bundles of electron-dense } \\
\text { tubules/filaments }\end{array}$ \\
\hline C2 & $\begin{array}{l}\text { Very long cilia with } \\
\text { membrane blebs } \\
\text { Short, finger-like } \\
\text { microvilli }\end{array}$ & $\begin{array}{l}\text { Euchromatic } \\
\text { nucleus } \\
\text { Rather dark } \\
\text { cytoplasm }\end{array}$ & Abundant RER & $\begin{array}{l}\text { Bundles of electron-dense } \\
\text { tubules/filaments }\end{array}$ \\
\hline S1 & None & $\begin{array}{l}\text { Heterochromatic } \\
\text { nucleus } \\
\text { Rather dark } \\
\text { cytoplasm }\end{array}$ & $\begin{array}{l}\text { Abundant RER } \\
\text { Golgi bodies }\end{array}$ & $\begin{array}{l}\text { Mucinogen granules (basally, with } \\
\text { an electron-dense mesh; apically, } \\
\text { with a looser electron-dense mesh) }\end{array}$ \\
\hline S2 & None & $\begin{array}{l}\text { Euchromatic } \\
\text { nucleus } \\
\text { Clear cytoplasm }\end{array}$ & $\begin{array}{l}\text { Abundant RER } \\
\text { Golgi bodies }\end{array}$ & $\begin{array}{l}\text { Granules with moderately } \\
\text { electron-dense cores }\end{array}$ \\
\hline G & - & $\begin{array}{l}\text { Euchromatic } \\
\text { nucleus } \\
\text { Clear cytoplasm }\end{array}$ & Golgi bodies & $\mathrm{R}$ granules \\
\hline
\end{tabular}
rough endoplasmic reticulum. 